\title{
Mercury in the terrestrial environment: a review
}

\author{
Barbara Gworek', Wojciech Dmuchowski ${ }^{1}$ and Aneta H. Baczewska-Dąbrowska ${ }^{2^{*}}$ (1)
}

\begin{abstract}
Background: Environmental contamination by mercury is and will continue to be a serious risk for human health. Pollution of the terrestrial environment is particularly important as it is a place of human life and food production. This publication presents a review of the literature on issues related to mercury pollution of the terrestrial environment: soil and plants and their transformations.

Results: Different forms of atmospheric $\mathrm{Hg}$ may be deposited on surfaces by way of wet and dry processes. These forms may be sequestered within terrestrial compartments or emitted back into the atmosphere, and the relative importance of these processes is dependent on the form of $\mathrm{Hg}$, the surface chemistry, and the environmental conditions. On the land surface, $\mathrm{Hg}$ deposition mainly occurs in the oxidized form $\left(\mathrm{Hg}^{2+}\right)$, and its transformations are associated primarily with the oxidation-reduction potential of the environment and the biological and chemical processes of methylation. The deposition of $\mathrm{Hg}$ pollutants on the ground with low vegetation is as 3-5 times lower than that in forests. The estimation of $\mathrm{Hg}$ emissions from soil and plants, which occur mainly in the $\mathrm{Hg}^{0}$ form, is very difficult. Generally, the largest amounts of $\mathrm{Hg}$ are emitted from tropical regions, followed by the temperate zone, and the lowest levels are from the polar regions. Areas with vegetation can be ranked according to the size of the emissions as follows: forests > other areas (tundra, savannas, and chaparral) > agricultural areas > grassland ecosystems; areas of land devoid of vegetation emit more $\mathrm{Hg}$ than those with plants. In areas with high pollution, such as areas near $\mathrm{Hg}$ mines, the $\mathrm{Hg}$ content in soil and plants is much higher than in other areas.
\end{abstract}

Conclusions: Mercury is recognized as a toxic, persistent, and mobile contaminant; it does not degrade in the environment and becomes mobile because of the volatility of the element and several of its compounds. Atmospheric contamination by mercury continues to be one of the most important environmental problems in the modern world. The general conclusions were drawn from a review of the literature and presented in this paper.

Keywords: Mercury, Deposition and emissions from land, Soil pollution, Content in plants

\section{Background}

Mercury is recognized as a toxic, persistent, and mobile contaminant; it does not degrade in the environment and becomes mobile because of the volatility of the element and several of its compounds. Moreover, mercury has the ability to be transported within air masses over very long distances [1].

\footnotetext{
*Correspondence: a.baczewska-dabrowska@obpan.pl

2 Polish Academy of Sciences Botanical Garden - Center for Biological

Diversity Conservation in Powsin, Prawdziwka 2 St, 02-973 Warsaw, Poland
}

Full list of author information is available at the end of the article
Over the last few decades, considerable scientific knowledge has been developed on the sources and emissions of mercury, its pathways and cycling through the environment, human exposure, and impacts on the environment and human health [2]. $\mathrm{Hg}$ is the only element in the periodic table to have its own environmental convention, i.e., the Minamata Convention on Mercury, thus highlighting the importance of the $\mathrm{Hg}$ pollution issue [3].

An improved understanding of the global mercury $(\mathrm{Hg})$ cycle is important for our capacity to predict how regulatory efforts to reduce current emissions to air, water and land will affect $\mathrm{Hg}$ concentrations in
Springer Open

(c) The Author(s) 2020. This article is licensed under a Creative Commons Attribution 4.0 International License, which permits use, sharing, adaptation, distribution and reproduction in any medium or format, as long as you give appropriate credit to the original author(s) and the source, provide a link to the Creative Commons licence, and indicate if changes were made. The images or other third party material in this article are included in the article's Creative Commons licence, unless indicated otherwise in a credit line to the material. If material is not included in the article's Creative Commons licence and your intended use is not permitted by statutory regulation or exceeds the permitted use, you will need to obtain permission directly from the copyright holder. To view a copy of this licence, visit http://creativeco mmons.org/licenses/by/4.0/. 
environmental compartments, biota and humans. $\mathrm{Hg}$ is released into the environment through human activities and via natural sources and processes, such as volcanoes and rock weathering. Following its release, $\mathrm{Hg}$ is transported and recycled between the major environmental compartments, i.e., air, soil and water, until it is eventually removed from the system through burial in coastal and deep ocean sediments, lake sediments, and subsurface soils $[2,4]$.

$\mathrm{Hg}$ is considered to be a peculiar chemical element because it displays particularly strong chemical and biological activity as well as variability in form (liquid and gaseous). $\mathrm{Hg}$ compounds with very different chemical and physical properties are included in various cycles of its natural circulation $[5,6] . \mathrm{Hg}$ is a globally distributed pollutant due to characteristics such as low melting and boiling points, conversions between chemical forms and participation in biological cycles. As a result of anthropogenic emissions, the global atmospheric $\mathrm{Hg}$ deposition rate is approximately three times higher than that in preindustrial times and has increased by a factor of $2-10$ in and around the most industrialized regions [7].

Hg-contaminated land environments pose a risk to global public health, with $\mathrm{Hg}$ being listed as one of the 'ten leading chemicals of concern' [8]. In 2013, the United Nations (UN) introduced the 'Minamata Convention on Mercury' [9], which aims for a more global effort for managing the risk presented by $\mathrm{Hg}$ to human health and the environment. The Minamata Convention has as of today 123 parties and the convention entered into force 16 August 2017. This concerted action, if successful, will have great implications for public health for decades to come; however, there are many hurdles on the way to achieving this goal $[10,11]$.

Our understanding of the critical processes driving global $\mathrm{Hg}$ cycling, particularly those that affect the large-scale exchange of $\mathrm{Hg}$ among major environmental compartments, has advanced substantially over the past decade. This progress has been driven by major advances in three interconnected areas: new data, new models, and new analytical tools and techniques [12].

The main task for improving our knowledge of mercury sources, fates, impacts, and emission control options was defined at the 14th ICMGP Conference in 2019 [13] as "Bridging knowledge on global mercury with environmental responsibility, human welfare and policy response". The main four questions that require urgent answers within this subject are defined as follows:

1. How is mercury biogeochemical cycling changing on global, regional, and local scales in response to per- turbations caused by major anthropogenic drivers of environmental change?

2. What is the relative risk of mercury exposure to human health and wildlife in the context of human welfare?

3. How can technological development contribute to the reduction in mercury exposure and improvement of environmental responsibility?

4. How can scientific knowledge contribute to the implementation and effectiveness evaluation of the Minamata Convention and other regulatory agreements, and what is the importance of integrating and implementing emerging and future mercury research into the policy making?

\section{Methods}

While developing this paper, the method recommended by Liberati et al. [14] was used to some extent. However, the strict use of this method was not possible due to the specifics of our publication. The problems of pollution and $\mathrm{Hg}$ transformation in the environment caused by significant threats to human health represent the subject of research by numerous research teams around the world. However, many publications do not meet the criterion of quality of research results. Therefore, the following criteria were used to eliminate publications:

i. Accurate descriptions of the research methods were lacking;

ii. Methods that did not guarantee the quality of the results were used;

iii. The latest publications were selected, but historical works were not omitted;

iv. Publications from various countries and regions were cited.

\section{Hg emission}

The advances achieved over the last decade for the assessment of $\mathrm{Hg}$ emissions from major man-made and natural sources have contributed to improvements in the assessments of the impacts of atmospheric deposition of $\mathrm{Hg}$ on the terrestrial environment [15]. The assessment of $\mathrm{Hg}$ emissions poses serious methodological problems. In estimating these impacts, state institutions mainly focus on inventories of their sources, while international organizations apply different models and use emission factors and statistical data of industrial production and consumption of Hg-containing materials. It is particularly difficult to distinguish natural and anthropogenic emissions from re-emissions from the land and oceans 
[16, 17]. Hg emission sources include both natural processes unfolding in the biosphere and anthropogenic sources. In 2008, the following classification was adopted in a UNEP report [18], which distinguished three emission sources:

- Current emissions from natural sources;

- Current emissions from anthropogenic sources;

- Re-emissions from historical deposits from natural and anthropogenic sources.

Environmental archives offer an opportunity to reconstruct temporal trends in atmospheric $\mathrm{Hg}$ deposition at various timescales. Lake sediment, peat, ice cores, tree rings, and $\mathrm{Hg}$ stable isotope measurements are offering new insights into historical $\mathrm{Hg}$ cycling. Preindustrial $\mathrm{Hg}$ deposition has been studied over decadal to millennial timescales extending as far back as the Late Pleistocene. Exploitation of mercury deposits (mainly cinnabar) first began during the Mid- to Late-Holocene in South America, Europe, and Asia, but increased dramatically during the Colonial era (1532-1900) for silver production [19, 20]. Artisanal gold mining is now thought responsible for over half the global stream flux of $\mathrm{Hg}$, followed by the burning of coal $[2,21]$.

Fluxes of $\mathrm{Hg}$ to the air occur via the volatilization of $\mathrm{Hg}^{0}$ as well as through wind entrainment of $\mathrm{Hg}$ bound to dust particles (often referred to as fugitive dust emissions). The relative magnitude of these two types of $\mathrm{Hg}$ emission sources varies depending on site-specific conditions. However, due to the long atmospheric lifetime of $\mathrm{Hg}^{0}$, these emissions mostly contribute to the global pool of $\mathrm{Hg}$, whereas the fugitive dust emissions impacts are more local [22].

The updated global mercury budget shows the impact of human activities on the mercury cycle and the resulting increase in mercury accumulated in soil and oceans.

Table 1 The updated global mercury budget [2] (Mg/year)

\begin{tabular}{|c|c|}
\hline \multicolumn{2}{|l|}{ Emission: } \\
\hline i) Natural (geogenic) & 500 \\
\hline \multicolumn{2}{|l|}{ ii) Re-emission/re-mobilization (natural and legacy): } \\
\hline Biomass burning & 600 \\
\hline From soil and vegetation & 1000 \\
\hline iii) Anthropogenic & $2500(2000-3000)$ \\
\hline iv) Ocean, net evasion (gaseous elemental Hg) & $3400(2900-4000)$ \\
\hline Total & 7000 \\
\hline \multicolumn{2}{|l|}{ Deposition: } \\
\hline i) To land/freshwater & 3600 \\
\hline ii) To ocean & 3880 \\
\hline Total & 7480 \\
\hline
\end{tabular}

The updated global mercury budget in 2018 [2] is shown in Table 1 . The annual deposits were 480 tons higher than the emissions, indicating considerable enrichment in the environment. In general [23, 24], $\mathrm{Hg}^{0}$ emissions from undisturbed nongeologically thermally enriched areas are $<1 \mathrm{ng} \mathrm{m}^{-2} \mathrm{~h}^{-1}$, whereas fluxes from contaminated sites can be several orders of magnitude higher at $>5000 \mathrm{ng} \mathrm{m}^{-2} \mathrm{~h}^{-1}$. For contaminated sites that cover large spatial areas (such as mining operations), the annual emissions from the entire surface area have been shown to range from 19 to $105 \mathrm{~kg}_{\text {year }}{ }^{-1}$ from active industrial gold mines and $51 \mathrm{~kg}$ year ${ }^{-1}$ from a large abandoned $\mathrm{Hg}$ mining area.

Various models are applied to estimate $\mathrm{Hg}$ emission levels into the atmosphere. However, the emission levels determined by using these models differ substantially. Travnikov et al. [25] compared the global emission levels from natural and anthropogenic sources determined by using four models [26-29]. The models differed significantly in their estimations of global total emissions, with values ranging from $4000 \mathrm{Mg}$ year $^{-1}$ to $9230 \mathrm{Mg}$ year $^{-1}$, of which natural emissions and re-emission ranged from 45 to $66 \%$ of the total emissions. A later summary of the four models [30] estimated that global anthropogenic emissions were $1870 \mathrm{Mg}$ year $^{-1}$, although the global natural emissions and re-emissions were already significantly different from each other at $3995 \mathrm{Mg}$ year $^{-1}$ to $8600 \mathrm{Mg}$ year $^{-1}$ [31]. The proportions between the amounts of natural emissions and anthropogenic emissions are not precisely determined. The ratios vary by authors and encompass a relatively wide range from 0.8 to 1.8 [32-34]. The relatively broad emission ranges presented in various studies are caused by the following factors: volatility of $\mathrm{Hg}$ compounds, distribution of sources, low levels of $\mathrm{Hg}$ concentrations in the air, concentrations

Table 2 Annual emissions of mercury by selected world region [11] (Mg/year)

\begin{tabular}{lrrcc}
\hline & $\mathbf{2 0 0 0}$ & $\mathbf{2 0 1 5}$ & $\begin{array}{l}\text { 2000-2015 } \\
\text { growth (\%/year) }\end{array}$ & $\begin{array}{l}\text { 2010-2015 } \\
\text { growth (\%/year) }\end{array}$ \\
\hline USA & 127.7 & 42.7 & -66.6 & -10.2 \\
OECD Europe & 106.2 & 38.0 & -64.2 & -5.8 \\
Canada & 12.7 & 8.3 & -34.6 & -3.2 \\
Eastern Europe & 49.4 & 33.6 & -32.0 & -1.3 \\
Central America & 33.5 & 34.3 & 2.4 & 5.4 \\
South Asia & 120.8 & 191.6 & 58.6 & 4.6 \\
Eastern Africa & 19.1 & 72.9 & 281.7 & 2.6 \\
East Asia & 532.7 & 1012.3 & 90.0 & 0.7 \\
South America & 239.0 & 275.8 & 15.4 & 2.2 \\
Southeast Asia & 224.6 & 187.5 & -16.5 & 1.8 \\
Global total & 1964.1 & 2389.8 & 21.7 & \\
\hline
\end{tabular}


that are much lower than levels of other basic pollutants and difficulty of determination $[35,36]$.

Annual mercury emissions in selected regions of the world in 2000-2015 are shown in Table 2. Despite the many applicable global, regional and national programs and conventions aimed at reducing $\mathrm{Hg}$ emissions, the global THg emissions in the years 2000-2015 increased by $1.8 \%$ [11]. Emission reductions only took place in North America and Europe without the former USSR, and the largest increase was in Central America (5.4\%) and South Asia (4.0\%).

Emission values [11] for the aggregated source categories and their composition are shown in Table 3. Three categories had the highest absolute value in 2015: gold ASMG (775.1 Mg/year), coal combustion (558.3 Mg/ year) and cement production (206.3 Mg/year). From 2010 to 2015, the largest increase in emissions was demonstrated by cement production $(6.3 \%)$, gold production at a large scale $(5.2 \%)$ and industrial metal extraction (4.6\%). The reductions [37] were in the following fields: dental $(-5.6 \%)$ and electrical equipment $(-5.2 \%)$. This finding is consistent with the continued expansion of the global economy, but is less than the growth in world GDP over the same period (5.7\%/year), suggesting continuous improvement in pollutant emissions per unit of production.

\section{Mercury emissions from natural sources}

The estimate of $\mathrm{Hg}$ emissions from natural sources includes contributions from primary natural sources and the re-emission processes of historically deposited $\mathrm{Hg}$ over land and sea surfaces. Hg emitted from volcanoes, geothermal sources and topsoil enriched in $\mathrm{Hg}$ pertains

Table 3 Annual emissions of mercury by selected source category [11] (Mg/year)

\begin{tabular}{lrrcc}
\hline $\begin{array}{l}\text { Source } \\
\text { category }\end{array}$ & $\mathbf{2 0 0 0}$ & $\mathbf{2 0 1 5}$ & $\begin{array}{l}\mathbf{2 0 0 0 - 2 0 1 5} \\
\text { growth (\%) } \\
\text { year) }\end{array}$ & $\begin{array}{l}\mathbf{2 0 1 0 - 2 0 1 5} \\
\text { growth (\%/year) }\end{array}$ \\
\hline Gold ASMG & 583.7 & 775.1 & 32.8 & 1.3 \\
Coal combustion & 359.9 & 558.3 & 55.1 & 0.7 \\
Cement produc- & 74.3 & 206.3 & 177.7 & 6.3 \\
$\quad$ tion & & & & 2.1 \\
Waste burning & 201.9 & 165.6 & -18.0 & 2.5 \\
Municipal waste & 202.6 & 140.6 & -30.6 & 5.2 \\
Gold, large-scale & 82.7 & 112.1 & 35.6 & 1.4 \\
Zinc smelting & 81.7 & 103.6 & 26.8 & 3.2 \\
Copper smelting & 53.7 & 70.0 & 30.4 & -5.6 \\
Dental & 49.4 & 16.1 & -67.4 & -5.2 \\
Electrical equip- & 118.7 & 62.0 & -94.8 & 1.8 \\
$\quad$ ment & & & & 21.7 \\
Global total & 1964.1 & 2389.8 & 21.7 \\
\hline
\end{tabular}

to primary natural sources, whereas the re-emission of previously deposited $\mathrm{Hg}$ on vegetation, land or water surfaces is primarily related to land use changes, biomass burning, meteorological conditions and gaseous $\mathrm{Hg}$ exchange mechanisms at the air-water/topsoil/snow-ice pack interfaces [15, 38].

A characteristic feature of natural $\mathrm{Hg}$ emissions compared to anthropogenic sources is their distributed nature and wide range of distribution. $\mathrm{Hg}$ from natural sources is introduced on a global scale into the atmosphere, and Hg from anthropogenic sources is deposited mainly locally and regionally; therefore, determining emission levels and applying effective control methods are difficult. Natural $\mathrm{Hg}$ emission processes also include re-emission of $\mathrm{Hg}$ previously deposited from the atmosphere in the process of wet and dry deposition from both natural and anthropogenic sources, which increases the difficulty of estimating $\mathrm{Hg}$ emissions from natural sources $[34,35,39]$.

Annual global $\mathrm{Hg}$ emissions from natural sources on land are estimated by various authors and cover a wide value range, e.g., total emissions of $1600-2500 \mathrm{Mg}$ year $^{-1}$, including re-emissions of 790-2000 $\mathrm{Mg}$ year $^{-1}$. According to most authors, re-emissions were higher than primary emissions [40-42].

\section{Volcanoes}

Volcanoes and geothermal activities are important sources of $\mathrm{Hg}$ pollution in terrestrial environments. $\mathrm{Hg}$ is emitted from volcanoes primarily as gaseous $\mathrm{Hg}^{0}$, and the $\mathrm{Hg} / \mathrm{SO}_{2}$ ratio is generally adopted to estimate $\mathrm{Hg}$ emissions. The annual average of $\mathrm{Hg}$ released to the atmosphere without episodic strong eruptions for volcanoes and geothermal activities is $\sim 75-112 \mathrm{Mg}$ year $^{-1}$ of $\mathrm{Hg}$, accounting for approximately $<2 \%$ of the contribution from natural sources [15, 43-45]. In volcanic plumes, $\mathrm{Hg}$ is present both in the gas phase as elemental $\mathrm{Hg}^{0}$ and reactive $\mathrm{Hg}^{\mathrm{II}}$ and in the particle phase as $\mathrm{Hg}_{\mathrm{p}}$ forms. The proportions of these species are highly variable. $\mathrm{Hg}^{\mathrm{II}}$ and $\mathrm{Hg}_{\mathrm{p}}$ typically amount to $<5 \%$ of $\mathrm{THg}$, with $\mathrm{Hg}^{\circ}$ as the most abundant form [46-48]. Hg levels in volcanic ash nanoparticles $\left(36 \pm 4 \mathrm{mg} \mathrm{kg}^{-1}\right)$ are dramatically higher than their bulk concentrations $\left(0.08 \mathrm{mg} \mathrm{kg}^{-1}\right)$ [49]. Many areas of geothermal activity have long been associated with elevated levels of $\mathrm{Hg}$ in the soil and air in places such as Hawaii, Iceland, western parts of the United States and New Zealand [43, 50].

The average annual global $\mathrm{Hg}$ emissions estimate from biomass burning (emissions from wildfires: forests, savannas and grasslands) for 1997-2006 was $675( \pm 240)$ Mg year ${ }^{-1}$, which accounts for $8 \%$ of all current anthropogenic and natural emissions. The largest $\mathrm{Hg}$ emissions are from tropical and boreal Asia, followed by Africa 
and South America [51, 52]. The important factor for $\mathrm{Hg}$ concentrations in forest soils is the time since standreplacing fires have occurred, and high soil burn severity has the potential to reduce the concentrations of $\mathrm{Hg}$ in burned soils for tens to hundreds of years [53, 54]. In a specific emission source in Nisyros Island (Greece), $\mathrm{Hg}$ concentrations in fumarolic gases in Nisyros Island (Greece) ranged from 10,500 to $46,300 \mathrm{ng} / \mathrm{m}^{3}$, while $\mathrm{Hg}$ concentrations in the air ranged from high background values in the Lakki Plain caldera $\left(10-36 \mathrm{ng} / \mathrm{m}^{3}\right)$ up to $7100 \mathrm{ng} / \mathrm{m}^{3}$ in the fumarolic areas [55].

\section{Exchange of mercury between atmospheric and terrestrial ecosystems}

Air-, soil- or vegetation-covered exchange fluxes are an important part of global and regional biogeochemical cycles [56]. Much of the $\mathrm{Hg}^{\mathrm{II}}$ deposited in precipitation or taken up by plants is reduced to $\mathrm{Hg}^{0}$ and may be released back to the atmosphere. Recent vegetation and soil $\mathrm{Hg}$ studies suggested that vegetation $\mathrm{Hg}^{0}$ uptake dominates (50-80\%) Hg net deposition at terrestrial sites [57-59].

The different forms of atmospheric $\mathrm{Hg}$ may be deposited on surfaces by way of wet and dry processes. These forms may be sequestered within terrestrial compartments or emitted back to the atmosphere, with the relative importance of these processes being dependent on the form of $\mathrm{Hg}$, surface chemistry, and environmental conditions. Many models assume that the net GEM (gaseous elemental mercury) exchange with soil surfaces is zero; however, as discussed below, some components are assimilated into foliage over the growing season and accumulate in soils [59]. Smith-Downey et al. [60] estimated that evasion of $\mathrm{Hg}$ linked to the decomposition of soil organic carbon pools and subsequent liberation of $\mathrm{Hg}^{\mathrm{II}}$ sorbed to soil organic matter is over $700 \mathrm{t} / \mathrm{y}$, thus reflecting the large pool of $\mathrm{Hg}$ stored in terrestrial ecosystems globally (over $240 \mathrm{kgt}$ ). In total, this study estimated that $56 \%$ of $\mathrm{Hg}$ deposited to terrestrial ecosystems is reemitted. Similarly, Graydon et al. [61] found that $45-70 \%$ of isotopically labeled $\mathrm{Hg}^{\mathrm{II}}$ wet-deposited to a forested watershed had been reemitted to the atmosphere after a year.

Litter deposition is the predominant source of $\mathrm{Hg}$ in soil. Forest litter horizons show significant increases in mass-dependent fractionation (MDF) during decomposition concurrent with augmented total Hg mass, and this relationship is most significant at high-elevation sites $[62$, 63]. Measurements of mercury in litterfall and throughfall have been increasingly used to provide knowledge of mercury deposition over forest canopies. The majority of mercury in litterfall is considered to be from the stomatal uptake of $\mathrm{Hg}^{0}$ and can be used as a rough and conservative estimation of atmospheric mercury dry deposition (the portion that is retained in leaves). Mercury in throughfall also includes a portion of previously dry-deposited mercury (the portion that is washed off from the canopy). Concurrent measurements of litterfall, throughfall, and open-space wet deposition measurements can be used to estimate dry deposition on seasonal or longer time scales, whereby dry deposition is approximated as litterfall plus throughfall minus open-space wet deposition $[64,65]$.

On the land surface, $\mathrm{Hg}$ deposition is mainly in the oxidized form $\left(\mathrm{Hg}^{2+}\right)$, and its transformations are associated primarily with the oxidation-reduction potential of the environment and with the biological and chemical processes of methylation. For soils in which oxidizing conditions predominate, the $\mathrm{Hg}^{2+}$ and $\mathrm{Hg}_{2}{ }^{2+}$ forms dominate, and in soils with reducing conditions, $\mathrm{Hg}$ and sulfur compounds are mainly present. Methyl-Hg compounds are most commonly found in soils with transient conditions [5].

For GEM $\left(\mathrm{Hg}^{0}\right)$, the residence time is estimated at 6 to 18 months, while GOM (gaseous mercury in oxidized form) and TPM (total particulate mercury) are quickly removed from the air through wet and dry deposition, and their residence times are estimated to be hours or days at most $[66,67]$. Given the long time for removal from the air, GEM can be transported over large distances [16]. The particular $\mathrm{Hg}$ species are characterized by different dry deposition rates, which also determine their residence times. The dry residence times of the different $\mathrm{Hg}$ species form the following series [68]:

GEM $0.19 \mathrm{~cm} \mathrm{~s}^{-1}<$ TPM 2:1 $\mathrm{cm} \mathrm{s}^{-1}<$ GOM 7:6 $\mathrm{cm} \mathrm{s}^{-1}$.

According to Marsik et al. [69], the dry deposition rates of GOM and GEM are much higher during daytime than nighttime. As with Lindberg et al. [68], these authors explain this fact by the closure of plant stomata at night. The deposition rates also depend on the type of surface [70]. Caffrey et al. [71] determined that the deposition rates of particulate air pollutants on the ground with low vegetation were 3-5 times lower than those in forests. Deposition is also affected by the weather conditions, air humidity, insolation and atmospheric precipitation. Research by Converse et al. [72] in an uncontaminated high-elevation wetland meadow in Shenandoah National Park, Virginia (USA) showed the highest $\mathrm{Hg}$ deposition occurred in spring $\left(4.8 \mathrm{ng} \mathrm{m}^{-2} \mathrm{~h}^{-1}\right)$, with a decrease occurring in summer $\left(2.5 \mathrm{ng} \mathrm{m}^{-2} \mathrm{~h}^{-1}\right)$ to near zero flux in fall $\left(0.3 \mathrm{ng} \mathrm{m}^{-2} \mathrm{~h}^{-1}\right)$, followed by an increase in winter emissions $\left(4.1 \mathrm{ng} \mathrm{m}^{-2} \mathrm{~h}^{-1}\right)$. These studies also suggest that stomatal processes are not the dominant mechanism for ecosystem-level GEM exchange. Table 4 shows a summary of biome-level $\mathrm{Hg}$ depositions and soil $\mathrm{Hg}$ turnover 
Table 4 Summary of biome-level $\mathrm{Hg}$ deposition and soil Hg turnover times [60]

\begin{tabular}{|c|c|c|c|c|}
\hline \multirow[t]{2}{*}{ Biome } & \multicolumn{2}{|c|}{$\begin{array}{l}\text { Mean Hg deposition } \\
\left(\mathrm{g} \mathrm{m}^{-2}\right)\end{array}$} & \multicolumn{2}{|c|}{$\begin{array}{l}\text { Mean soil } \mathrm{Hg} \text { turnover } \\
\text { time }^{\mathrm{a}} \text { (years) }\end{array}$} \\
\hline & Preindustrial & $\begin{array}{l}\text { Present } \\
\text { day }\end{array}$ & Preindustrial & Present day \\
\hline $\begin{array}{l}\text { Tropical } \\
\text { forest }\end{array}$ & 0.9 & 3.7 & 234 & 126 \\
\hline $\begin{array}{l}\text { Temperate } \\
\text { forest }\end{array}$ & 0.8 & 2.9 & 250 & 151 \\
\hline $\begin{array}{l}\text { Boreal } \\
\text { forest }\end{array}$ & 0.5 & 1.5 & 998 & 560 \\
\hline Grassland & 1.0 & 3.5 & 522 & 269 \\
\hline Tundra & 0.3 & 0.8 & 1108 & 702 \\
\hline Desert & 0.5 & 1.4 & 2387 & 1748 \\
\hline
\end{tabular}

${ }^{a}$ With respect to respiration

times [60]. The concentration of $\mathrm{Hg}$ in soils is therefore a function of the deposition rate and carbon turnover time. High soil concentrations in desert ecosystems are driven by a combination of higher deposition and extremely slow $\mathrm{Hg}$ turnover. Tropical and temperate lifetimes are similar despite the faster carbon turnover in tropical systems due to the relative balance between $\mathrm{Hg}$ provided by wet deposition and leaf uptake.

Emissions from soils have the form of GEM and depend on many factors [73-77]:

- The properties of soils, e.g., $\mathrm{Hg}$ content, the contents of organic compounds, and saturation;

- The concentrations of oxidants, mainly ozone, in the air;

- The weather conditions, e.g., solar radiation, temperature, humidity and winds.

Soil Hg fluxes are significantly lower in dark conditions than light conditions for all sites except grassland [64].

It is most difficult to estimate $\mathrm{Hg}$ emissions from plants, and these emissions mainly occur in the form of $\mathrm{Hg}^{0}$ [78-80]. Ericksen et al. [81] suggested the following hierarchy of environmental parameters that influence $\mathrm{Hg}$ flux:

Soil moisture $>$ light $>$ air concentration $>$ relative humidity $>$ temperature.

Table 5 shows a summary of total $\mathrm{Hg}$ ( $\mathrm{THg}$ ) fluxes from terrestrial regions [38], and Table 6 shows the average fluxes (or, in some cases, the range of fluxes) for various ecosystems measured by a number of investigators.

When analyzing the data in Table 6, the following generalizations can be made [38, 82]:
Table 5 Summary of mercury fluxes from terrestrial regions [38]

\begin{tabular}{lcc}
\hline Region & $\begin{array}{l}\text { Evasion } \\
\text { (average) } \\
\text { (Mg year }^{-1} \text { ) }\end{array}$ & $\begin{array}{l}\text { Ratio }^{\text {a }} \\
\text { (\%) }\end{array}$ \\
\hline Forest & 342 & 7,5 \\
Tundra/grassland/savannah/prairie/chaparral & 448 & 9,9 \\
Desert/metalliferous/non-vegetated zones & 546 & 12,0 \\
Agricultural areas & 128 & 2,8 \\
Evasion after mercury depletion events & 200 & 4,4 \\
Total & 1664 & - \\
Volcanoes and geothermal areas & 90 & - \\
Biomass burning & 675 & - \\
\hline
\end{tabular}

${ }^{a}$ Calculated over the total evasion from natural sources which sum $4532 \mathrm{Mg}$ year $^{-1}$

${ }^{\mathrm{b}}$ Friedli [42] and Mason [68] distinguish as a natural source of mercury emission to the atmospheric air of regions where there are episodes of sudden decreases in mercury concentrations in the air by deposition to the ground and then reemission. These phenomena occur mainly in the Arctic regions and Antarctica, and the emission from this source is estimated at $200 \mathrm{Mg}$ year $^{-1}$

i. The largest amounts of $\mathrm{Hg}$ are emitted from tropical regions (45\%), followed by the temperate zones (41\%), with the lowest emissions from the polar regions $(8 \%)$, and emissions from volcanoes and geothermal areas account for 5\%;

ii. Areas with vegetation can be ranked according to the size of their emissions as follows: forests > other areas (tundra, savannas, and chaparral) $>$ agricultural areas $>$ grassland ecosystems;

iii. Land areas devoid of vegetation emit more $\mathrm{Hg}$ than do areas with plants.

Deforestation can increase GEM emissions due to higher solar radiation and increased temperature at the soil surface $[83,84]$.

The overall background soil $\mathrm{Hg}$ flux in the United States is estimated to be $0.9 \pm 0.2 \mathrm{ng} / \mathrm{m}^{2} / \mathrm{h}$ [78], and in areas with significant $\mathrm{Hg}$ pollution, soil emissions are much larger. In the canton of Valais, Switzerland, elemental $\mathrm{Hg}\left(\mathrm{Hg}^{0}\right)$ is undetectable in soil, although substantial $\mathrm{Hg}^{0}$ emissions were found to occur $\left(20-1392 \mathrm{ng} \mathrm{m}^{-2} \mathrm{~h}^{-1}\right)$ [85].

Urban areas are of particular concern with respect to the global Hg cycle due to the following [86]:

i. Frequently high terrestrial $\mathrm{Hg}$ concentrations and the physically and chemically diverse nature of urban surface covers;

ii. Highly variable time series concentrations of ambient atmospheric $\mathrm{Hg}$ as a result of regional and local emissions;

iii. Urban meteorology (i.e., heat island effect). 


\begin{tabular}{|c|c|c|}
\hline Species/ecosystem & $\begin{array}{l}\text { Flux } \\
\text { nmol m } \\
-2 \\
\text { month }^{-1}\end{array}$ & References \\
\hline Ground-level forest floor Sweden & $1.4-1.7$ & $\begin{array}{l}\text { Hanson et al. [82] } \\
\text { Lindberg et al. [68] }\end{array}$ \\
\hline Model estimates hard wood forest & $\operatorname{Max} 4$ & Bash et al. [196] \\
\hline Model estimates forest soil & 4 & Bash et al. [196] \\
\hline Agricultural crops & Max 11 & Bash et al. [196] \\
\hline Temperate forest & 5.0 & Rea et al. [197] \\
\hline Deforested site & 50 & Magarelli and Fostier [198] \\
\hline Desert soils & $3.6-9.8$ & Magarelli and Fostier [198] \\
\hline High Hg regions & Max 1500 & Gustin and Lindberg [199] \\
\hline Maple & 20 & Hanson et al. [82] \\
\hline Oak & 16.4 & Hanson et al. [82] \\
\hline Spruce & 6.1 & Hanson et al. [82] \\
\hline Prairie grass & 12.5 & Obrist et al. [53] \\
\hline Typha sp. & 60 & Gustin et al. [200] \\
\hline Average global soil & 1.5 & Selin et al. [201] \\
\hline
\end{tabular}

${ }^{a}$ Values have all been converted to a common flux unit of $\mathrm{nmol} \mathrm{m}^{-2} \mathrm{month}^{-1}$. Results from the older literature are combined in estimates given in various review papers

In the city of Tuscaloosa, Alabama (USA), Hg fluxes on bare undisturbed soil surfaces were as follows (median) [86]:

- Residential site -4.45 ng. $\mathrm{m}^{-2} \mathrm{~h}^{-1}$;

- Industrial site-1.40 ng. $\mathrm{m}^{-2} \mathrm{~h}^{-1}$;

- Commercial site-2.14 ng. $\mathrm{m}^{-2} \mathrm{~h}^{-1}$;

- Mixed land use site-0.87 ng. $\mathrm{m}^{-2} \mathrm{~h}^{-1}$.

Areas of land devoid of vegetation emit more $\mathrm{Hg}$ than those with plants. The annual averaged fluxes in the subtropical forest zones in China from soil in the forests were $14.2 \mathrm{ng} \mathrm{m}^{-2} \mathrm{~h}^{-1}$, and for open-air sites, they were $20.7 \mathrm{ng} \mathrm{m}^{-2} \mathrm{~h}^{-1}$ [87]. Soil $\mathrm{Hg}$ fluxes were significantly lower in dark conditions than in light conditions. In grassland sites, the mean soil $\mathrm{Hg}$ flux was $0.6 \pm 0.9 \mathrm{ng} \mathrm{m}^{-2} \mathrm{~h}^{-1}$ in darkness, $1.0 \pm 0.7 \mathrm{ng} \mathrm{m}^{-2} \mathrm{~h}^{-1}$ in light, and $0.9 \pm 0.7 \mathrm{ng} \mathrm{m}^{-2} \mathrm{~h}^{-1}$ overall [64].

Cropland is an important component of terrestrial ecosystems. It is estimated that $33 \%$ of natural-source atmospheric $\mathrm{Hg}$ comes from the emissions at cropland surfaces [88]. The emission of $\mathrm{Hg}$ from cropland soil greatly affects the global $\mathrm{Hg}$ cycle. Combinations of different crop cultivars and planting densities will result in different light transmittance under canopies, which directly affects the solar and heat radiation flux received by the soil surface below crops. In turn, this might lead to differences in the soil-air total gaseous mercury (TGM) exchange under different cropping patterns. The light transmittance under the canopy was the key control on soil-air TGM exchange fluxes. High light transmittance can enhance soil TGM emission rates and increase the magnitude of diurnal variations in soil-air TGM exchange fluxes. The estimated annual average soil-air TGM exchange flux was $5.46 \pm 21.69 \mathrm{ng} \mathrm{m}^{-2} \mathrm{~h}^{-1}$ in corn-wheat rotation cropland with $30 \mathrm{~cm}$ row spacing $[89,90]$.

The bidirectional exchange of $\mathrm{Hg}$ between the atmosphere and terrestrial surfaces is better understood because of advancements in research that are primarily associated with the interpretation from $\mathrm{Hg}$ isotopes, and the latest estimates place land surface $\mathrm{Hg}$ re-emission at values lower than previously thought [91].

\section{Methylmercury}

High doses of organic compounds of $\mathrm{Hg}$, particularly methyl-Hg, can be fatal to humans and wildlife, and even relatively low doses can seriously affect the nervous system of organisms. Hg has also been linked to harmful effects on the cardiovascular, immune and reproductive systems. Methyl-Hg passes through both the placenta and blood-brain barrier; therefore, the exposure of women of child-bearing age and of children to methylmercury is of great concern [1].

Methyl-Hg can be both biotically and abiotically produced in the environment. Methylation of $\mathrm{Hg}$ tends to occur in environments with low oxygen levels, low $\mathrm{pH}$, $\mathrm{Hg}$ bioavailability, temperature, redox potential and high levels of dissolved organic compounds and in environments favored by sulfate-reducing bacteria, which are largely responsible for methylation. These conditions 
are found primarily in deep sea environments, coastal marine sediments, and some freshwater lakes as well as soils. These conditions are also characteristic for paddy soil [92, 93]. Organic $\mathrm{Hg}$ is much more toxic to living organisms than inorganic $\mathrm{Hg}[4,94,95]$. The content of methyl-Hg in soils and plants is significantly lower than that of THg; however, due to its much higher toxicity, methyl- $\mathrm{Hg}$ is particularly dangerous for living organisms. In soils in the coniferous boreal forests of Sweden, the background level of pollution from methyl-Hg accounted for $0.35-0.59 \%$ of $\mathrm{THg}$ [96]. In the Idrija $\mathrm{Hg}$ mining area of Slovenia, a heavily polluted region, methyl-Hg accounted for $0.003 \%$ of $\mathrm{THg}$, and its background presence in controls was $0.17 \%$ [97]. The content of methyl$\mathrm{Hg}$ relative to THG was $1.9 \%$ in the roots of rice under background conditions and $0.55 \%$ in the leaves; in areas of $\mathrm{Hg}$ mining sites, the concentrations were $0.07 \%$ in the roots and $0.01 \%$ in the leaves; and in areas with artisanal $\mathrm{Hg}$ mining sites, the concentrations were $0.63 \%$ in the roots and $0.02 \%$ in the leaves [98]. Methyl-Hg in heavily contaminated soil in the Rhône Valley (Switzerland) accounted for $<0.8 \%$ of $\mathrm{THg}$ [99].

A number of factors that control microbial activity and/or the geochemical speciation of inorganic $\mathrm{Hg}^{2+}$ govern $\mathrm{MeHg}$ formation in the environment [100]. Microorganisms that live in soil can transform inorganic $\mathrm{Hg}^{(\mathrm{II})}$ species into $\mathrm{Hg}^{0}$ by using the enzyme $\mathrm{Hg}$ reductase, which is found in various bacteria, such as Pseudomonas sp., Staphylococcus aureus, Thiobacillus and many others [101]. Increases in temperature might lead to increases in biological activity as well as higher $\mathrm{Hg}^{2+}$ methylation rates [102].

The direct conversion of insoluble $\mathrm{HgS}$ species to $\mathrm{MeHg}$ in anaerobic soils is generally believed to be low, although this condition can change when environmental conditions favor $\mathrm{HgS}$ complexation [103]. The redox potential also seems to be a key factor, as suboxic and mildly reducing conditions seem to promote high $\mathrm{Hg}^{2+}$ methylation rates, while anoxic and strongly reducing conditions might lead to elevated sulfide concentrations that eventually prevent $\mathrm{Hg}^{2+}$ from being available for methylation of some methylating bacteria, including SRB (sulfate-reducing bacteria, e.g., Desulfobacter sp.), and some that control the availability of $\mathrm{Hg}^{2+}$ for methylation (e.g., Deltaproteobacteria or Clostridia) [104, 105].

$\mathrm{S}$ plays a major role in influencing $\mathrm{Hg}^{2+}$ methylation by directly affecting the activity of some methylating bacteria, such as SRB, and controlling the availability of $\mathrm{Hg}^{2+}$ for methylation [106, 107].

The paddy soils in $\mathrm{Hg}$ mining areas have a high methylation ability and may eventually result in heavily biological effects on the local residents through the food chains, such as rice containing high methyl-Hg [108].
In the Wuchuan $\mathrm{Hg}$ mining areas (Guizhou, China), soil samples present $\mathrm{THg}$ values ranging from 0.33 to $320 \mathrm{mg} \mathrm{kg}{ }^{-1}$ and methyl- $\mathrm{Hg}$ values ranging from 0.69 to $20 \mathrm{ng} \mathrm{g}^{-1}$. The rice grain samples contain elevated methyl- $\mathrm{Hg}$ concentrations ranging from 4.2 to $18 \mathrm{ng} \mathrm{g}^{-1}$, while corn grain contained only $0.5-2.0 \mathrm{ng} \mathrm{g}^{-1}$ [92]. Research carried out in areas with coal-fired power plants in Hunan (China) [109] shows that in the soil samples, $\mathrm{THg}$ varied from 0.068 to $0.220 \mathrm{mg} \mathrm{kg}^{-1}$ (mean value of $0.130 \pm 0040 \mathrm{mg} \mathrm{kg}^{-1}$ ), and methyl- $\mathrm{Hg}$ ranged from 0.30 to $3.5 \mu \mathrm{g} \mathrm{kg}^{-1}$ (mean $1.6 \pm 1.0 \mu \mathrm{g} \mathrm{kg}^{-1}$ ). In rice samples, the $\mathrm{Hg}^{\text {(II) }}$ concentrations varied from 0.002 to $0.022 \mathrm{mg} \mathrm{kg}^{-1}$ (mean $0.057 \mathrm{mg} \mathrm{kg}^{-1}$ ), and methyl-Hg concentrations varied from 1.7 to $3.8 \mathrm{ng} \mathrm{gg}^{-1}$ (mean of $\left.2.4 \pm 0.72 \mathrm{ng} \mathrm{g}^{-1}\right)$. Meng et al. [98] showed that rice had high affinity for methyl- $\mathrm{Hg}$ and that the concentrations in rice seeds may be 2 to 3 orders of magnitude higher in $\mathrm{Hg}$ mining sites than in other local edible crop plants. Freshly deposited $\mathrm{Hg}$ is more likely to methylate and be incorporated in rice than stored $\mathrm{Hg}$ [91].

Forest fires cause a significant reduction in mercury content in soil. Burned soils in northwestern Ontario (Canada) had $82 \%$ less methyl-Hg than fresh soils [110]. Current climate change has had a significant impact on $\mathrm{Hg}$ transformation processes, especially in the Arctic. The very large mass of mainly natural $\mathrm{Hg}$ found in northern permafrost deposits, which is projected to be released with further climate warming, may profoundly affect biotic $\mathrm{Hg}$ levels around the Northern Hemisphere, especially because large amounts of organic carbon, which may stimulate $\mathrm{Hg}$ methylation rates, will be simultaneously released [111].

\section{Mercury in soil}

Mercury has a relatively long half-life in surface soils because of its recycling between the surface environment and atmosphere. Permanent removal of anthropogenic $\mathrm{Hg}$ from the biologically active part of the environment will only occur once it is buried in mineral soils [4]. Soil plays an important role in biogeochemical $\mathrm{Hg}$ circulation because it accumulates this element and is a source for other environmental components. Hg occurs naturally in soils from geologic sources [12] or as the result of natural events such as forest fires and volcanic eruptions [49]. The total amount worldwide of $\mathrm{Hg}$ accumulated in the soils of terrestrial environments is estimated at 200-300 Gg [112-114]. Smith-Downey et al. [60] suggested that organically bound $\mathrm{Hg}$ in preindustrial soils is $200 \mathrm{Gg}$ and that a $20 \%$ increase in organically bound soil $\mathrm{Hg}$ (to 240 $\mathrm{Gg}$ ) has occurred from preindustrial steady-state conditions to the present day.

In the 2013 Technical Background Report for the Global Mercury Assessment [4], based on a global model 
and budget developed by Mason et al. [114], human activities were estimated to cumulatively increase atmospheric $\mathrm{Hg}$ concentrations by $300-500 \%$ over the past century. Because of the naturally high $\mathrm{Hg}$ amount present in soil, the average $\mathrm{Hg}$ increase was only $20 \%$ in surface organic soil and negligible in mineral soils. The revolatilization of "legacy $\mathrm{Hg}$ " (i.e., $\mathrm{Hg}$ from historical sources of pollution) from soil and ocean and its long residence time in those compartments contribute to maintaining atmospheric $\mathrm{Hg}$ concentrations and deposition rates at higher levels than those supported by current primary emissions [115]. Recent estimates of the anthropogenic and natural $\mathrm{Hg}$ contents in global soils (organic layers) (data in kilotons) included 182 natural and 89 anthropogenic sources based on Amos et al. [116] and 130 natural and 20 anthropogenic sources according to the AMAP/ UN Environment [4].

All results for $\mathrm{Hg}$ soil content, which are presented in the next part of this publication, pertain to the topsoil layer. Generally, the average background concentration of $\mathrm{Hg}$ in soil ranges from 0.03 to $0.1 \mathrm{mg} \mathrm{kg}^{-1}$, with an average value of $0.06 \mathrm{mg} \mathrm{kg}^{-1}$, whereas $\mathrm{Hg}$-contaminated sites often have soil concentrations that are 2- to 4-orders of magnitude higher $[117,118]$. Kabata Pendias and Pendias [5] defined a narrower range of $0.05-0.3 \mathrm{mg} \mathrm{kg}^{-1}$, although some volcanic and organic soils, especially in Canada, may contain higher values, and in the vicinity of industrial emission sources, the values can be extremely high. Obrist et al. [119] showed that a dataset with more than 1900 randomly selected sampling points across the western USA indicated median $\mathrm{Hg}$ concentrations of $0.019 \mathrm{mg} \mathrm{kg}^{-1}$ and an average value of $24 \mathrm{mg} \mathrm{kg}^{-1}$, with only $1 \%$ of soil samples exceeding background values (e.g., > $0.10 \mathrm{mg} \mathrm{kg}^{-1}$ ).

The LUCAS Topsoil Survey of the European Union organization collected over 23,000 topsoil samples (upper $20 \mathrm{~cm}$ ) from land in all European Union countries (28) except for Croatia [120]. The average for European topsoil $\mathrm{Hg}$ concentrations was $0.04 \mathrm{mg} \mathrm{kg}^{-1}$, with a range of $0-159 \mathrm{mg} \mathrm{kg}^{-1}$. Studies have identified highly polluted, isolated sites, and the larger historical and recent industrial and $\mathrm{Hg}$ mining areas show elevated concentrations of $\mathrm{Hg}$. Historically, mining for gold and $\mathrm{Hg}$ led to high $\mathrm{Hg}$ concentrations in these mining areas, which may explain the high $\mathrm{Hg}$ concentrations in some samples from Central Italy, Northwest England and Eastern Slovakia. Moreover, the natural/background $\mathrm{Hg}$ level was $0.08 \mathrm{mg} /$ $\mathrm{kg}$ in Brazil [121], $0.05 \mathrm{mg} / \mathrm{kg}$ in India [122], $0.23 \mathrm{mg} / \mathrm{kg}$ in New Zealand [123], $0.11 \mathrm{mg} / \mathrm{kg}$ in the Norwegian Arctic [124] and $0.4 \mathrm{mg} / \mathrm{kg}$ in Paris [125]. Most soil $\mathrm{Hg}$ was found as soil matrix-bound divalent $\mathrm{Hg}\left(\mathrm{Hg}^{\mathrm{II}}\right)$, whereas elemental $\mathrm{Hg}\left(\mathrm{Hg}^{0}\right)$ was undetectable in soils $[85,99]$.
Table 7 presents examples of the concentrations of $\mathrm{Hg}$ in the soils in the vicinity of industrial emission sources according to different authors, The highest $\mathrm{Hg}$ contents were found in soils near $\mathrm{Hg}$ mines: Almaden in Spain, with 2000 years of mining and ore processing $\left(<8889 \mathrm{mg} \mathrm{kg}^{-1}\right)$ [126]; Idrija in Slovenia, with 500 years of mining activity $\left(<2759 \mathrm{mg} \mathrm{kg}^{-1}\right)$ [97, 127]; and in Alaska (5326 mg kg-1) [125]. Chlor-alkali plants are also an important source of environmental $\mathrm{Hg}$ pollution. Bernaus et al. [128] estimated that Hg levels in the soil around a chlor-alkali plant in the Netherlands were as high as $1150 \mathrm{mg} \mathrm{kg}^{-1}$.

According to Richardson and Moore [129], in the urban environment, the diversity of $\mathrm{Hg}$ content in soils is relatively high because of the diversity of land functions in towns. Urban soils were found to accumulate higher concentrations and pools of $\mathrm{Hg}$ than their rural montane counterparts across New York and southern New England, which highlights the importance of soils in urban systems for sequestering $\mathrm{Hg}$ and preventing its movement towards riparian and aquatic ecosystems, where it can bioaccumulate. Moreover, soil $\mathrm{Hg}$ concentrations were poorly correlated with $\mathrm{pH}$, loss-on-ignition, and clay content. Instead, proximity to local industrial and agricultural sources proved a significant influence on $\mathrm{Hg}$ accumulation.

The lowest median results were determined for soils in Changchun, China, at $0.018 \mathrm{mg} \mathrm{kg}{ }^{-1}$, with a range of $0.012-0.036 \mathrm{mg} \mathrm{kg}^{-1}$ [130] and in Oslo, Norway $\left(0.06 \mathrm{mg} \mathrm{kg}^{-1}\right.$, with a range of $\left.0.01-2.3 \mathrm{mg} \mathrm{kg}^{-1}\right)$ [131], while the highest concentrations were in Palermo, Italy (median value of $1.85 \mathrm{mg} \mathrm{kg}^{-1}$, with a range of $0.004-$ $\left.2.61 \mathrm{mg} \mathrm{kg}^{-1}\right)$ [132], and Glasgow, Scotland (1.2 $\mathrm{mg} \mathrm{kg}^{-1}$, with a range of $0.312-5.2 \mathrm{mg} \mathrm{kg}^{-1}$ ) [133]. Of note is the reduction of $270 \%$ (median from $0.68 \mathrm{mg} \mathrm{kg}^{-1}$ to 0.37 ) in $\mathrm{Hg}$ pollution from 1987 to 2009 for soils from Beijing, China [134].

In agricultural soils, pollution by $\mathrm{Hg}$ was relatively low, as indicated by the low median and average values at usually below $0.1 \mathrm{mg} \mathrm{kg}^{-1}$ (e.g., Scandinavia-Ottesen et al. [135]; Poland-Loska et al. [136]; Iran-Ahmadi et al. [137]). However, the ranges of the results were relatively wide, and the maximum values often exceeded $1 \mathrm{mg} \mathrm{kg}$, which may indicate a threat to food production due to the need to protect human health in some areas with higher $\mathrm{Hg}$ soil levels. In Europe, pastures were slightly more polluted with $\mathrm{Hg}$ than plowed fields [136]. Soils in forest environments contained low levels of $\mathrm{Hg}$. Average and median values did not exceed $1 \mathrm{mg} \mathrm{kg}^{-1}$, although compared with agricultural soils, the maximum values were also lower than $1 \mathrm{mg} \mathrm{kg}^{-1}$. Mineral forest soils contained less $\mathrm{Hg}$ than organic ones (USAWoodruff and Cannon, [54] Czech Republic-Navrátil 
Table 7 Some examples of surface soil layer contamination with mercury in regions of important sources of emissions by various authors

\begin{tabular}{|c|c|c|c|c|c|c|}
\hline Country & Location & Source of pollution & Period & $\begin{array}{l}\text { Total Hg } \\
\mathbf{m g ~ k g}^{-1}\end{array}$ & Mean/median & Author \\
\hline USA & Alaska & Hg-mining & & $0.05-5326$ & & Bailey et al. [125] \\
\hline USA & Texas & Hg-mining & & $3.8-11$ & & Gray et al. [202] \\
\hline China & Wuchuan & Hg-mining & 2003 & $0.33-320$ & & Qiu et al. [92] \\
\hline China & Wanshan & Hg-mining & 2002 & $5.1-790$ & & Qiu et al. [108] \\
\hline China & Xiaoqinling & Gold mining & & $0.04-61.2$ & Mean 2.75 & Wu et al. [203] \\
\hline \multirow[t]{2}{*}{ Slovenia } & Idrija & Hg-mining & 1991-97 & $1734-2759$ & Mean 2456 & Gnamuš et al. [97] \\
\hline & & Hg-mining & 2000-01 & $24-1055$ & Median 47 & Gosar et al. [127] \\
\hline Slovenia & Podljubelj & Hg-mining & 2003-04 & $0.35-244$ & Median 3.7 & Teršič et al. [204] \\
\hline Slovakia & Rudnany & Hg-mining & & $9.1-54.3$ & & Banásová [205] \\
\hline Spain & Almaden & Hg-mining & & $6-8889$ & Mean 604 & Higueras et al. [126] \\
\hline Spain & Almaden & Hg-mining & & $1340-4830$ & & Dago et al. [157] \\
\hline Spain & Caunedo & Old Hg-mining & & $0.09-50.0$ & Mean 13.1 & Boente et al. [206] \\
\hline Italy & Vallalta & Old Hg-mining & & $6-21$ & & Wahsha et al. [207] \\
\hline Turkey & Halıköy & Hg mining & 2004 & $0.10-33$ & Mean 5.5 & Gemici et al. [208] \\
\hline China & Tongguan & Artisanal gold mining & & $0.69-23.7$ & Mean 2.91 & Xiao et al. [209] \\
\hline China & Wanshan & Hg-mining, artisanal gold & 2012 & $0.5-187$ & Mean 31.0 & Yin et al. [210] \\
\hline China & Guizhou & Acetic acid & 2016 & $1.09-3.71$ & & Li et al. [93] \\
\hline Italy & Mt. Amiata, & Hg mining, volcano-geothermal & & $2.4-68$ & & Chiarantini et al. [211] \\
\hline France & Vosges Mountains & Chlor-alkali & 2002 & $0.16-3.99$ & & Hissler and Probst [212] \\
\hline France & Grenoble & Chlor-alkali & & $1.3-10$ & & Grangeon et al. [213] \\
\hline Kazakhstan & Pavlodar & Chlor-alkali & & $0.93-22.3$ & & Ullrich et al. [214] \\
\hline Spain & Flix & Chlor-alkali & & $0.04-12.9$ & Mean 0.77 & Esbrí et al. [215] \\
\hline Germany & & Chlor-alkali & & $0.5-4.2$ & Mean 1.6 & Biester et al. [216] \\
\hline Netherlands & & Chlor-alkali & 2004 & $4.3-1150$ & & Bernaus et al. [128] \\
\hline Portugal & Estarreja & Chlor-alkali & & $0.010-91$ & Mean 5.4 & Reis et al. [217] \\
\hline China & Huludao & Chlor-alkali Zn-smelting & $2006-08$ & $0.05-14.6$ & & Zheng et al. [218] \\
\hline China & An Ning & Chlor-alkali & & $0.09-1.30$ & Mean 0.40 & Song et al. [219] \\
\hline China & Kunming & Chlor-alkali polyvinyl chloride & & $0.15-4.79$ & & Zhu et al. [220] \\
\hline Portugal & Caveira & Sulfide mine & & $1.1-76.5$ & & Reis et al. [221] \\
\hline China & Lianyuan & Coal main, steel industry & 2015 & $1.20-3601$ & Mean 178 & Liang et al. [222] \\
\hline China & Zhuzhou & Zn/Pb smelter & 2012 & $0.62-2.61$ & Mean 1.54 & Wu et al. [223] \\
\hline China & Chongqing & Thermometer factory & & $0.06-0.88$ & & Wang et al. [224] \\
\hline Czech Rep. & Bohemian & non-ferrous metal & 2017 & 6.49 & & Navrátil et al. [225] \\
\hline Switzerland & Canton of Valais & Industrial region & 2017 & $0.2-390$ & & Osterwalder et al. [85] \\
\hline Poland & Warsaw & Thermometer factory & 2005 & $122-393$ & Mean 147 & Boszke et al. [140] \\
\hline Pakistan & Karachi/Lahore & Highway & & $61.5-144$ & Mean 90.7 & Khan et al. [226] \\
\hline Germany & Rhine-Westph. & Floodplain soil & 2017 & 31.2 & & Beckers et al. [227] \\
\hline Italy & Etna & Volcano & & $0.1-0.4$ & & Bonanno et al. [228] \\
\hline European Union & & 23,000 samples & $2009-12$ & $0-1.59$ & Mean 0.04 & Tóth et al. [120] \\
\hline
\end{tabular}

et al. [138]; Sweden-Åkerblom et al. [139]. According to Obrist et al. [119], soil Hg concentrations significantly differed among land covers following the order:

Forested upland $>$ planted/cultivated $>$ herbaceous upland/shrubland $>$ barren soils.

Concentrations in forests were an average of 2.5 times higher than those in barren locations.
The global distributions of soil $\mathrm{Hg}$ storage and emissions for both preindustrial and present-day simulations in different biomes are shown in Table 4 [60]. The relatively low soil Hg concentrations in boreal and arctic ecosystems are driven by extremely low deposition. The high soil concentrations in desert ecosystems are driven by a combination of higher deposition and extremely slow $\mathrm{Hg}$ 
turnover. The concentration of $\mathrm{Hg}$ in soils is therefore a function of the deposition rate and carbon turnover time.

Physical and chemical properties of the soil affect the $\mathrm{Hg}$ cycle in the environment. The soil aggregate size fractions have significant effects on the $\mathrm{Hg}$ content in soil. The concentrations of $\mathrm{Hg}$ and other heavy metals in soils and sediments generally tend to increase with decreasing grain size, which is due to the propensity of metals to bind with finer particles [140]. Generally, higher values of $\mathrm{Hg}$ in soil are found in the fraction at $<63 \mu \mathrm{m}$ [141]. In the Amazonian areas without anthropogenic sources, the fine fraction $(<53 \mu \mathrm{m})$ of podzolized soils had higher $\mathrm{Hg}$ contents than clayey soils [142]. In a temperate forest podzol, $\mathrm{Hg}$ mean values increased as the aggregate sizes decrease, as follows:

Clay $\left(170 \mathrm{ng}^{-1} \mathrm{~g}^{-1}\right)>$ fine silt $\left(130 \mathrm{ng} \mathrm{g}^{-1}\right)>$ coarse silt $\left(80 \mathrm{ng} \mathrm{g}^{-1}\right)>$ fine sand $\left(32 \mathrm{ng}^{-1}\right)>$ coarse sand $\left(14 \mathrm{ng} \mathrm{g}^{-1}\right)$.

Total Hg enrichment in clay-sized aggregates were 2 to 11 times higher than the values shown by the bulk soil $(<2 \mathrm{~mm})$ [143]. In a heavily polluted area near the Wanshan $\mathrm{Hg}$ mine (China), the fine soil aggregate size fractions $<231 \mu \mathrm{m}$ showed higher total $\mathrm{Hg}$ concentrations and higher soil organic matter content than did the larger aggregate size fractions (231 to $2000 \mu \mathrm{m}$ ) [144].

Humic acid influences $\mathrm{Hg}$ transport and transformation in soil-plant systems, especially for soils having low clay content. Humic acid reduces the amount of available $\mathrm{Hg}$ in soil and prevents $\mathrm{Hg}$ from being transported into plants or leached from the soil. Leaching can result in $\mathrm{Hg}$ leaking into natural water systems under normal environmental conditions. In practice, humic acid can be used to control $\mathrm{Hg}$ transportation into food chains from soil heavily polluted by $\mathrm{Hg}$ [145].

The chemical and mineralogical properties of soil affect oxidation and retention of atmospheric $\mathrm{Hg}$. Abiotic $\mathrm{Hg}$ oxidation occurs because organic matter has - $\mathrm{SH}$ groups, which have a high affinity for $\mathrm{Hg}$ ions, and $\mathrm{Hg}$ oxidation is favored in the presence of compounds with high affinities for the $\mathrm{Hg}$ ion [121]. A microbial contribution to $\mathrm{Hg}$ oxidation was first proposed by Smith et al. [146], who demonstrated that typical soil bacteria (Bacillus and Streptomyces) can oxidize elemental $\mathrm{Hg}$ to $\mathrm{Hg}^{2+}$ through enzymatic paths. Recent studies have shown that $\mathrm{Hg}$ can also be oxidized by anaerobic bacteria $[147,148]$. The soil microbial community is very sensitive to $\mathrm{Hg}$ concentrations, and this sensitivity is influenced not only by soil properties, but also by the plant species growing in the soil. A level of $0.36 . \mathrm{mg} \mathrm{kg}^{-1}$ of $\mathrm{Hg}$ in soils is proposed to be a critical concentration above which plant and soil organisms will be affected [121].

\section{Mercury in plants}

Vegetation affects environmental factors at the ground surface by reducing solar radiation, temperature, and wind velocity and serves as a surface for $\mathrm{Hg}$ uptake [84]. Many studies have recognized the essential role of terrestrial plants in the biogeochemical cycling of $\mathrm{Hg}$ (e.g., Gustin et al. [149]; Fantozzi et al. [150]; Mazur et al. [151]).

Approximately $80 \%$ of total $\mathrm{Hg}$ accumulated in the aboveground biomass is found in the leaves, and approximately $1 \%$ of that $\mathrm{Hg}$ is methylated. The concentrations of $\mathrm{Hg}$ in aspen tissue grown in high- $\mathrm{Hg}$ soil increases in the following order [152]:

Stems $<$ branches $<$ petioles $<$ roots $<$ leaves.

Research conducted by Leonard et al. [153] in Nevada (USA) in an area with high levels of $\mathrm{Hg}$ contamination revealed that for the plant species Lepidium latifolium, $70 \%$ of the $\mathrm{Hg}$ taken up by the roots during the growing season was emitted to the atmosphere.

The main source of $\mathrm{Hg}$ in leaves comes from air pollution with $\mathrm{Hg}^{0}$ and not from soil contamination [149, 154, 155]. The studies by Fleck et al. [156] of Pinus resinosa have shown that neither woody tissue $\mathrm{Hg}$ nor any amount of $\mathrm{Hg}$ in the soil or forest floor were closely related to foliar levels, while for some relationships, the opposite was true. The authors interpret these data as indicating that $\mathrm{Hg}$ in plant tissues is derived directly from the atmosphere and not from the soil. It is estimated that in highly contaminated soils, generally less than $2 \%$ of the $\mathrm{Hg}$ present is available for plants [157]. Total leaf concentrations of $\mathrm{Hg}$ varied among species and were most closely correlated with the number of stomates per sample, thus supporting the hypothesis that stomatal uptake of atmospheric $\mathrm{Hg}$ (most likely $\mathrm{Hg}^{0}$ ) is a potential uptake pathway [158]. Research by Arnold et al. [159] also indicated the importance of the nonstomatal pathway for the uptake of total gaseous $\mathrm{Hg}$ (TGM).

Plants growing beyond the influence of high $\mathrm{Hg}$ emissions contained less than $100 \mathrm{ng} \mathrm{g}^{-1} \mathrm{THg}$. Plants growing in the vicinity of factories are large emitters of $\mathrm{Hg}$, such as those around $\mathrm{Hg}$ mining sites (e.g., Moreno-Imenez et al. [160]; Qian et al. [161]) and chlor-alkali mining sites [162]. Au mining sites [163, 164] may also contain extremely high $\mathrm{Hg}$ contents. Mushrooms have been identified as organisms that accumulate more $\mathrm{Hg}$ than other plants [165]. A synthesis of published vegetation $\mathrm{Hg}$ data from the western United States showed that aboveground biomass concentrations followed the order [119]:

Leaves $\left(26 \mu \mathrm{g} \mathrm{kg}^{-1}\right) \sim$ branches $\left(26 \mu \mathrm{g} \mathrm{kg}^{-1}\right)>$ bark $\left(16 \mu \mathrm{g} \mathrm{kg}^{-1}\right)>$ bole wood $\left(1 \mu \mathrm{g} \mathrm{kg}{ }^{-1}\right)$.

$\mathrm{Hg}$ concentrations in leaves were monitored from the emergence to senescence and showed a strong positive correlation with leaf age $[155,158,166]$. 


\section{Toxic effects on plants}

$\mathrm{Hg}$ does not have any beneficial effects on organisms and is thus regarded as the "main threat" since it is very harmful to both plants and animals; pollutes the air, water and soil; and is toxic [167]. Mercury has toxic effects on plants, even at low concentrations, and leads to growth retardation [168] and many other adverse effects [105].

$\mathrm{Hg}$ in plants is strongly bound to sulfhydryl/thiol groups of proteins and forms $\mathrm{SHgS}$. Hg toxicity in plants occurs via its binding to $\mathrm{SH}$ groups of proteins, displacement of essential elements and disruption of the protein structure [169]. This biochemical property probably determines the toxic effects on plants $[5,170,171]$. Studies of the toxic effects of $\mathrm{Hg}$ on soil organisms and native plants in fields are limited. The effects of $\mathrm{Hg}$ are usually examined in sterile and much-simplified laboratory conditions, which may differ from field conditions to varying degrees [172].

The field study of Moreno-Jiménez et al. [160] was conducted in the mining district of Almadén (Spain), which is a cinnabar $(\mathrm{HgS})$ enriched zone, from which one-third of the total $\mathrm{Hg}$ produced worldwide is extracted. Mining activity began more than 2000 years ago, and no other region in the world has been influenced by $\mathrm{Hg}$ for such a long period. The region is considered to be one of the regions most polluted by $\mathrm{Hg}$ in the world. $\mathrm{Hg}$ concentrations in the field plants Rumex induratus and Marrubium vulgare grown in these soils can be considered phytotoxic, although no symptoms of $\mathrm{Hg}$ toxicity have been observed in any of the studied plant species. In most contaminated soils and mine tailings, $\mathrm{Hg}$ is not readily available for plant uptake [173].

The absorption of organic and inorganic $\mathrm{Hg}$ from soil by plants is low, and there is a barrier to Hg translocation from plant roots to tops. Thus, large increases in soil $\mathrm{Hg}$ levels produce only modest increases in plant $\mathrm{Hg}$ levels by direct uptake from soil [172]. In terrestrial vegetation, $\mathrm{Hg}$ in the aboveground biomass originates primarily from the atmosphere, whereas $\mathrm{Hg}$ in the roots comes from the soil $[67,174]$. The research conducted by Lomonte et al. [175] suggested the existence of $\mathrm{Hg}$ stress-activated defense mechanisms in plants and hypothesized that these mechanisms were likely the reason for the increased production of sulfur compounds in the tested plant species, which stimulated their growth. $\mathrm{Hg}$ has very limited solubility in soil, low availability for plant uptake and no known biological function, which may explain why $\mathrm{Hg}$-hyperaccumulating plants have not yet been identified, meaning that a method for Hg phytoremediation in soils contaminated with $\mathrm{Hg}$ has not yet been developed [175]. However, studies suggesting the use of transgenic plants for phytoremediation have been published recently [176, 177].
The significant toxic effect of $\mathrm{Hg}$ on plants is the generation of reactive oxygen species (ROS) [178], e.g., superoxide anion radicals, $\mathrm{H}_{2} \mathrm{O}_{2}$, and hydroxyl radicals $(\mathrm{OH}$.) $[179,180]$. Detoxification mechanisms to combat $\mathrm{Hg}$ induced oxidative stress include enzymatic antioxidants and some nonenzymatic antioxidants, such as the following: glutathione [181], phytochelatin [182], salicylic acids [183], ascorbic acid [184], selenium, [185], proline [186] and tocopherols [187]. This process is correlated with the disruption of biomembrane lipids and cellular metabolism, resulting in plant injury [188].

Increasing levels of mercury species in the soil exert a wide range of adverse effects on the growth and metabolism of plants $[167,189,190]$, such as reduced photosynthesis, transpiration, water uptake, chlorophyll synthesis $[188,191,192]$ and increased lipid peroxidation (Cho and Park [179]). A high Hg content in plants affects the activity of most enzymes. The total activity of stress indicators such as superoxide dismutase (SOD), peroxidase (POD) and ascorbate peroxides (APX) increased after $\mathrm{Hg}$ treatment, but the vast majority of enzymes were inhibited at higher concentrations (e.g., Manikandan et al. [193]; Mahbub et al. [194]; Zhou et al. [195]).

\section{Conclusions and commentary}

Atmospheric contamination by mercury continues to be one of the most important environmental problems in the modern world. The following general conclusions can be drawn from this review of the literature and are accompanied by the authors' critical commentary:

- Models differ significantly in their estimations of global total $\mathrm{Hg}$ emissions-from 4000 to $9230 \mathrm{Mg}$ year $^{-1}$ - of which natural emissions and reemissions ranged from 45 to $66 \%$.

- Many factors contribute to such large differences in the assessments of the level of global emissions: (i) methodological difficulties exist in assessing re-emission from heavily polluted areas under the influence of contemporary and historical emissions and areas with background pollution; (ii) the transformation of various forms of $\mathrm{Hg}$ depends on many difficult to evaluate processes, which makes estimating emissions difficult; and (iii) unusual phenomena associated with the transformation of various $\mathrm{Hg}$ forms (e.g., mercury depletion events (MDEs), which consist of episodes of sudden drops in total gaseous mercury concentrations in the air in the Antarctic and Arctic, can occur.

- Despite the many applicable global, regional and national programs and conventions aimed at reducing $\mathrm{Hg}$ emissions, global total $\mathrm{Hg}$ emissions in the 
years $2000-2015$ increased by $1.8 \%$. In many countries, including those with a high national income, there is a lack of understanding by society at large and politicians about the need to reduce emissions.

- The proportions between the amounts of natural emissions and anthropogenic emissions have not been precisely determined. This ratio, which is dependent on the authors, has been estimated over a relatively wide range of $0.8-1.8$.

- Annual global Hg emissions from natural sources on land are estimated by various authors over a wide range, with total emissions of $1600-2500 \mathrm{Mg} \mathrm{year}^{-1}$, including re-emissions of $790-2000 \mathrm{Mg}$ year $^{-1}$. The low share of $\mathrm{Hg}$ taken up by plants from the soil is beneficial from perspective of protecting food against contamination, although it also limits the possibility of using plants in the phytoremediation of contaminated soils.

- On the land surface, $\mathrm{Hg}$ deposition is mainly in the oxidized form $\left(\mathrm{Hg}^{2+}\right)$, and its transformations are associated primarily with the oxidation-reduction potential of the environment and the biological and chemical processes of methylation.

- The main source of Hg in plant leaves comes from air pollution with $\mathrm{Hg}^{0}$ and not from soil contamination. It is very difficult to estimate $\mathrm{Hg}$ emissions from plants, which mainly occur in the form of $\mathrm{Hg}^{0}$.

- Methyl-Hg can be produced both biotically and abiotically in the environment. Methylation of $\mathrm{Hg}$ tends to occur in environments with low oxygen levels, low $\mathrm{pH}, \mathrm{Hg}$ bioavailability, temperature, redox potential and high dissolved organic compound levels, and environments favored by SRB are largely responsible for this methylation.

- Rice growing conditions mean that the Hg methylation process is extremely intensive. Consequently, rice may contain significantly more $\mathrm{Hg}$ than other crops, which is particularly dangerous because rice in many regions of the world is the basis for feeding the population.

- Hg has very limited solubility in soil and low availability for plant uptake, and it does not have any known biological function. These factors may explain why Hg-hyperaccumulating plants have not yet been identified, meaning that an effective phytoremediation methods for soil contaminated with $\mathrm{Hg}$ has not yet been developed, which may explain why $\mathrm{Hg}$ hyperaccumulator plants have not found practical use in phytoremediation of contaminated soils. Such work may be more applicable in wetland environments. The possibility of using contaminated soil in phytoremediation by transgenic plants is promising and a future research direction.
- A large number of scientific publications have been devoted to the problem of $\mathrm{Hg}$ environmental pollution. However, these studies face many difficulties: (i) analytical difficulties exist, which are caused by very low $\mathrm{Hg}$ contents in all elements of the environment; (ii) the need to determine a specific form of $\mathrm{Hg}$ prohibits providing results in total $\mathrm{Hg}$; and (iii) the form in which $\mathrm{Hg}$ occurs depends on many environmental factors that must be accurately recognized and described. Unfortunately, many scientific publications do not meet these requirements.

\section{Abbreviations}

Hg: Mercury; UN: United Nations; UNEP: United Nations Environment Programme; GEM: Gaseous elemental mercury $\mathrm{Hg}^{0}$; GOM: Gaseous mercury in oxidized form; TPM: Total particulate mercury; TGM: Total gaseous Hg; ROS: Reactive oxygen species; $\mathrm{OH}$ : Hydroxyl radicals; SOD: Superoxide dismutase; POD: Peroxidase; APX: Ascorbate peroxides.

\section{Acknowledgements}

Not applicable.

\section{Authors' contributions}

WD has been responsible for the concept of the manuscript and drafted the manuscript. BG and AH B-D helped to further elaborate the manuscript. All authors improved the final manuscript. All authors read and approved the final manuscript.

\section{Funding}

The work was financed from the Own Research Fund Institute of Environment Protection - National Research Institute.

\section{Availability of data and materials}

Not applicable; presented information is based on previously published data only.

\section{Ethics approval and consent to participate}

Not applicable.

Consent for publication

Not applicable.

\section{Competing interests}

The authors declare that they have no competing interests.

\section{Author details}

${ }^{1}$ Institute of Environmental Protection - National Research Institute, Warsaw, Poland. ${ }^{2}$ Polish Academy of Sciences Botanical Garden - Center for Biological Diversity Conservation in Powsin, Prawdziwka 2 St, 02-973 Warsaw, Poland.

Received: 9 March 2020 Accepted: 14 September 2020

Published online: 02 October 2020

\section{References}

1. Pacyna JM (2020) Recent advances in mercury research. Sci Total Environ 738:139955. https://doi.org/10.1016/j.scitotenv.2020.139955

2. Environment UN (2019) Global mercury assessment 2018. UN Environment Programme, Chemical and Health Branch Geneva, Switzerland

3. Bank MS (2020) The mercury science-policy interface: history, evolution and progress of the Minamata Convention. Sci Total Environ 722:137832. https://doi.org/10.1016/j.scitotenv.2020.137832 
4. AMAP, UN Environment (2019) Technical background report for the global mercury assessment 2018. Arctic Monitoring and Assessment Programme, Oslo, Norway/UN Environment Programme, Chemicals and Health Branch, Geneva, Switzerland

5. Kabata-Pendias A, Pendias H (2001) Trace elements in soils and plants, 3rd edn. CRC Press, Boca Raton. https://doi.org/10.1201/9781420039 900

6. Newman MC (2014) Fundamentals of ecotoxicology: the science of pollution, 4th edn. CRC Press, Boca Raton. https://doi.org/10.1201/b17658

7. Hylander LD, Meili M (2003) 500 years of mercury production: global annual inventory by region until 2000 and associated emissions. Sci Total Environ 304:13-27. https://doi.org/10.1016/S0048-9697(02)00553 $-3$

8. WHO (2017) Ten chemicals of major health concern. http://www.who. int/ipcs/assessment/public_health/chemicals_phc/en/index.html

9. Minamata Convention on Mercury. (2020). http://www.mercurycon vention.org/Portals/11/documents/conventionText/Minamata

10. Selin H, Keane SE, Wang S, Selin NE, Davis K, Bally D (2018) Linking science and policy to support the implementation of the Minamata Convention on Mercury. Ambio 47:198-215. https://doi.org/10.1007/ s13280-017-1003-x

11. Streets DG, Horowitz HM, Lu Z, Levin L, Thackray CP, Sunderland EM (2019) Global and regional trends in mercury emissions and concentrations. 2010-2015. Atmos Environ 201:417-427. https://doi. org/10.1016/j.atmosenv.2018.12.031

12. Obrist D, Kirk JL, Zhang L, Sunderland EM, Jiskra M, Selin NE (2018) A review of global environmental mercury processes in response to human and natural perturbations: changes of emissions, climate, and land use. Ambio 47:116-140. https://doi.org/10.1007/s1328 0-017-1004-9

13. ICMGP 2019) 14th international conference on mercury as a global pollutant, 8-13 September 2019 Cracow, Poland. http://www.mercury201 9krakow.com

14. Liberati A, Altman DG, Tetzlaff J, Mulrow C, Gøtzsche PC, loannidis JP et al (2009) The PRISMA statement for reporting systematic reviews and meta-analyses of studies that evaluate health care interventions: explanation and elaboration. J Clin Epidemiol 62:1-34. https://doi. org/10.1016/j.jclinepi.2009.06.006

15. Pirrone $N$, Cinnirella S, Feng $X$, Finkelman RB, Friedli HR, Leaner J et al (2010) Global mercury emissions to the atmosphere from anthropogenic and natural sources. Atmos Chem and Phys 10:5951-5964. https ://doi.org/10.5194/acp-10-5951-2010

16. Pacyna EG, Pacyna JM, Sundsetha K, Munthec J, Kindbomc K, Wilsond S et al (2010) Global emission of mercury to the atmosphere from anthropogenic sources in 2005 and projections to 2020. Atmos Environ 44:2487-2499. https://doi.org/10.1016/j.atmosenv.2009.06.009

17. Gworek B, Dmuchowski W, Baczewska AH, Brągoszewska P, BemowskaKałabun O, Wrzosek-Jakubowska J (2017) Air contamination by mercury, emissions and transformations_-a review. Water Air Soil Poll 228:123. https://doi.org/10.1007/s11270-017-3311-y

18. UNEP Chemical Branch (2008) The global atmospheric mercury assessment: sources, emissions and transport. UNEP-Chemicals, Geneva

19. Cooke CA, Martínez-Cortizas A, Bindler R, Gustin MS (2020) Environmental archives of atmospheric $\mathrm{Hg}$ deposition - a review. Sci Total Environ 709:134800. https://doi.org/10.1016/.scitotenv.2019.134800

20. Miszczak E, Stefaniak S, Michczyński A, Steinnes E, Twardowska I (2020) A novel approach to peatlands as archives of total cumulative spatial pollution loads from atmospheric deposition of airborne elements complementary to EMEP data: priority pollutants $(\mathrm{Pb}, \mathrm{Cd}, \mathrm{Hg})$. Sci Total Environ 705:135776. https://doi.org/10.1016/.scitotenv.2019.135776

21. Zhu C, Tian H, Hao J (2020) Global anthropogenic atmospheric emission inventory of twelve typical hazardous trace elements, 1995-2012. Atmos Environ 220:117061. https://doi.org/10.1016/j.atmosenv.2019.117061

22. Eckley C, Blanchard P, McLennan D, Mintz R, Sekela M (2015) Soil-air mercury flux near a large industrial emission source before and after closure (Flin Flon, Manitoba, Canada). Environ Sci Techno 49:9750-9757. https://doi.org/10.1021/acs.est.5b01995

23. Eckley CS, Gilmour CC, Janssen S, Luxton TP, Randall PM, Whalin L et al (2020) The assessment and remediation of mercury contaminated sites: a review of current approaches. Sci Total Environ 707:136031. https:// doi.org/10.1016/j.scitotenv.2019.136031
24. Agnan Y, Le Dantec T, Moore CW, Edwards GC, Obrist D (2016) New constraints on terrestrial surface-atmosphere fluxes of gaseous elemental mercury using a global database. Environ Sci Technol 50:507-524. https ://doi.org/10.1021/acs.est.5b04013

25. Travnikov O, Dastoor A, Bullock R, Christensen JH (2008) Modeling atmospheric transport and deposition. In: AMAP/UNEP, technical background report to the global atmospheric mercury assessment. Arctic Monitoring and Assessment Programme, UNEP Chemical Branch, pp 79-107

26. Dastoor AP, Larocque Y (2004) Global circulation of atmospheric mercury: a modelling study. Atmos Environ 38:147-161. https://doi. org/10.1016/j.atmosenv.2003.08.037

27. Henze DK, Hakami A, Seinfeld JH (2007) Development of the adjoint of GEOS-Chem. Atmos Chem Phys 79:2413-2433. https://resolver.calte ch.edu/CaltechAUTHORS:HENacp07

28. Seigneur C, Vijayaraghavan K, Lohman K, Levin L (2009) The AER/EPRI global chemical transport model for mercury (CTM-HG). In: Pirrone N, Mason R (eds) Mercury fate and transports in the global atmosphere. Springer, New York, pp 589-602

29. Travnikov O, llyin I (2009) The EMEP/MSC-E mercury modeling system. In: Pirrone N, Mason R (eds) Mercury fate and transports in the global atmosphere. Springer, New York, pp 571-587. https://doi. org/10.1007/978-0-387-93958-2_20

30. Travnikov O, Angot H, Artaxo P, Bencardino M, Bieser J, D'Amore F et al (2017) Multi-model study of mercury dispersion in the atmosphere: atmospheric processes and model evaluation. Atmos Chem Phys. https ://doi.org/10.5194/acp-17-5271-201

31. De Simone F, Gencarelli CN, Hedgecock IM, Pirrone N (2014) Global atmospheric cycle of mercury: a model study on the impact of oxidation mechanisms. Environ Sci Pollut R 21:4110-4123. https://doi. org/10.1007/s11356-013-2451-x

32. Nriagu JO, Pacyna JM (1998) Quantitative assessment of worldwide contamination of air, water and soils by trace metals. Nature 333:134139. https://doi.org/10.1038/333134a0

33. Shetty SK, Lin CJ, Streets DG, Jang C (2008) Model estimate of mercury emission from natural sources in East Asia. Atmos Environ 42:86748685. https://doi.org/10.1016/j.atmosenv.2008.08.026

34. Liu G, Cai Y, O'Driscoll N, Feng X, Jiang G (2012) Overview of mercury in the environment. In: Liu G, Cai Y, O'Driscoll N (eds) Environmental chemistry and toxicology of mercury. Wiley, Hoboken, pp 1-12

35. Gustin MS, Lindberg SE, Austin K, Coolbaugh M, Vette A, Zhang H (2000) Assessing the contribution of natural sources to regional atmospheric mercury budgets. Sci Total Environ 259:61-71. https://doi.org/10.1016/ S0048-9697(00)00556-8

36. Gustin MS, Lindberg SE, Weisberg PJ (2008) An update on the natural sources and sinks of atmospheric mercury. Appl Geoch 23:482-493. https://doi.org/10.1016/j.apgeochem.2007.12.010

37. Streets DG, Horowitz HM, Jacob DJ, Lu Z, Levin L, Ter Schure AF et al (2017) Total mercury released to the environment by human activities. Environ Sci Technol 51:5969-5977. https://doi.org/10.1021/acs. est.7b00451

38. Mason RP (2009) Mercury emissions from natural processes and their importance in the global mercury cycle. In: Pirrone N, Mason R (eds) Mercury fate and transports in the global atmosphere. Springer, New York, pp 173-191. https://doi.org/10.1007/978-0-387-93958-2_7

39. Wang Y, Greger M (2004) Clonal differences in mercury tolerance, accumulation, and distribution in willow. J Environ Qual 33:1779-1785. https ://doi.org/10.2134/jeq2004.1779

40. Bergan T, Gallardo L, Rohde H (1999) Mercury in the global troposphere-a three-dimensional model study. Atmos Environ 33:15751585. https://doi.org/10.1016/S1352-2310(98)00370-7

41. Mason RP, Sheu GR (2002) Role of the ocean in the global mercury cycle. Global Biogeoch Cy 16:1093. https://doi.org/10.1029/2001GB001440

42. Lamborg CH, Fitzgerald WF, O'Donnell J, Torgersen T (2002) A non-steady-state compartmental model of global-scale mercury biogeochemistry with interhemispheric atmospheric gradients. Geochim Cosmochim Ac 66:1 105-1118. https://doi.org/10.1016/S0016 $-7037(01) 00841-9$

43. Nriagu J, Becker C (2003) Volcanic emissions of mercury to the atmosphere: global and regional inventories. Sci Total Environ 304:3-12. https ://doi.org/10.1016/S0048-9697(02)00552-1 
44. Pyle DM, Macher RA (2003) The importance of volcanic emissions for the global atmospheric mercury cycle. Atmos Environ 37:5115-5124. https://doi.org/10.1016/j.atmosenv.2003.07.011

45. Bagnato E, Aiuppa A, Parello F, Allard P, Shinohara H, Liuzzo M et al (2011) New clues on the contribution of Earth's volcanism to the global mercury cycle. B Volcanol 73:497-510. https://doi.org/10.1007/s0044 5-010-0419-y

46. Bagnato E, Aiuppa A, Parello F, Calabrese S, D'Alessandro W, Mather TA et al (2007) Degassing of gaseous (elemental and reactive) and particulate mercury from Mount Etna volcano (Southern Italy). Atmos Environ 41:377-7388. https://doi.org/10.1016/j.atmosenv.2007.05.060

47. Witt MLI, Mather TA, Pyle DM, Aiuppa A, Bagnato E, Tsanev VI (2008) Mercury and halogen emissions from Masaya and Telica volcanoes. J Geophys Res Solid Earth, Nicaragua. https://doi.org/10.1029/2007J B005401

48. Martin RS, Witt MLI, Pyle DM, Mather TA, Watt SFL, Bagnato E et al (2011) Rapid oxidation of mercury $(\mathrm{Hg})$ at volcanic vents: insights from high temperature thermodynamic models of Mt Etna's emissions. Chem Geol 283:279-286. https://doi.org/10.1016/j.chemg eo.2011.01.027

49. Ermolin MS, Fedotov PS, Malik NA, Karandashev VK (2018) Nanoparticles of volcanic ash as a carrier for toxic elements on the global scale. Chemosphere 200:16-22. https://doi.org/10.1016/j.chemospher e.2018.02.089

50. Coolbaugh M, Gustin M, Rytuba J (2002) Annual emissions of mercury to the atmosphere from natural sources in Nevada and California. Environ Geol 42:338-349. https://doi.org/10.1007/s0025 4-002-0557-4

51. Cinnirella S, Pirrone N (2006) Spatial and temporal distributions of mercury emissions from forest fires in Mediterranean region and Russian federation. Atmos Environ 40:7346-7361. https://doi.org/10.1016/j. atmosenv.2006.06.051

52. Friedli HR, Arellano AF, Cinnirella S, Pirrone N (2009) Mercury emissions from global biomass burning: spatial and temporal distribution. In: Mason R, Pirrone N (eds) Mercury fate and transport in the global atmosphere. Springer, Boston. https://doi.org/10.1007/978-0-387-93958 $-2 \_8$

53. Obrist D, Gustin MS, Arnone JA III, Johnson DW, Schorran DE, Verburg PS (2005) Measurements of gaseous elemental mercury fluxes over intact tallgrass prairie monoliths during one full year. Atmos Environ 39:957-965. https://doi.org/10.1016/j.atmosenv.2004.09.081

54. Woodruff LG, Cannon WF (2010) Immediate and long-term fire effects on total mercury in forests soils of northeastern Minnesota. Environ Sci Technol 44:5371-5376. https://doi.org/10.1021/es100544d

55. Gagliano AL, Calabrese S, Daskalopoulou K, Cabassi J, Capecchiacci F, Tassi F et al (2019) Degassing and cycling of mercury at nisyros volcano (Greece). Geofluids. https://doi.org/10.1155/2019/4783514

56. Pierce AM, Moore CW, Wohlfahrt G, Hörtnagl L, Kljun N, Obrist D (2015) Eddy covariance flux measurements of gaseous elemental mercury using cavity ring-down spectroscopy. Environ Sci Technol 49:15591568. https://doi.org/10.1021/es505080z

57. Obrist D, Johnson DW, Lindberg SE (2009) Mercury concentrations and pools in four Sierra Nevada forest sites, and relationships to organic carbon and nitrogen. Biogeosciences 6:765-777. https://doi.org/10.1016/j. atmosenv.2004.09.081

58. Jiskra M, Sonke JE, Obrist D, Bieser J, Ebinghaus R, Myhre CL et al (2018) $A$ vegetation control on seasonal variations in global atmospheric mercury concentrations. Nat Geosci 11:244-250. https://doi.org/10.1038/ s41561-018-0078-8

59. Gustin MS (2012) Exchange of mercury between the atmosphere and terrestrial ecosystems. In: Liu G, Cai Y, O'Driscoll N (eds) Environmental chemistry and toxicology of mercury. Wiley, Hoboken, pp 423-451

60. Smith-Downey NV, Sunderland EM, Jacob DJ (2010) Anthropogenic impacts on global storage and emissions of mercury from terrestrial soils: insights from a new global model. Biogeosci, J Geophys Res. https ://doi.org/10.1029/2009JG001124

61. Graydon JA, St. Louis VL, Lindberg SE, Sandilands KA, Rudd JW, Kelly CA et al (2012) The role of terrestrial vegetation in atmospheric $\mathrm{Hg}$ deposition: pools and fluxes of spike and ambient $\mathrm{Hg}$ from the METAALICUS experiment. Global Biogeochem Cy 26:GB1022. https:// doi.org/10.1029/2011GB004031
62. Zheng W, Obrist D, Weis D, Bergquist BA (2016) Mercury isotope compositions across North American forests. Global Biogeoch Cy 30:1475-1492. https://doi.org/10.1002/2015GB005323

63. Sommar J, Osterwalder S, Zhu W (2020) Recent advances in understanding and measurement of $\mathrm{Hg}$ in the environment: surface-atmosphere exchange of gaseous elemental mercury $\left(\mathrm{Hg}^{0}\right)$. Sci Total Environ. https://doi.org/10.1016/j.scitotenv.2020.137648

64. Wright LP, Zhang L, Marsik FJ (2016) Overview of mercury dry deposition, litterfall, and throughfall studies. Atmos Chem Phys 16:13399. https://doi.org/10.5194/acp-16-13399-201

65. Lyman SN, Cheng I, Gratz LE, Weiss-Penzias P, Zhang L (2020) An updated review of atmospheric mercury. Sci Total Environ 707:135575. https://doi.org/10.1016/j.scitotenv.2019.135575

66. Skov H, Bullock R, Christensen JH, Sørensen LL (2008). Atmospheric pathways. In: AMAP/UNEP, technical background report to the global atmospheric mercury assessment. Arctic Monitoring and Assessment Programme, UNEP Chemical Branch, pp 64-72

67. Selin NE, Jacob DJ, Park RJ, Yantosca RM, Strode S, Jaeglé L et al (2007) Chemical cycling and deposition of atmospheric mercury: global constraints from observations. J Geophys Res 112:D02308. https://doi. org/10.1029/2006JD007450

68. Lindberg SE, Dong W, Meyers T (2002) Transpiration of gaseous elemental mercury through vegetation in a subtropical wetland in Florida. Atmos Environ 36:5207-5219. https://doi.org/10.1016/S1352 $-2310(02) 00586-1$

69. Marsik FJ, Keeler GJ, Landis MS (2007) The dry-deposition of speciated mercury to the Florida Everglades: measurements and modeling. Atmos Environ 41:136-149. https://doi.org/10.1016/j.atmos env.2006.07.032

70. Hanson PJ, Lindberg SE, Tabberer TA, Owens JA, Kim KH (1995) Foliar exchange of mercury vapor: evidence for a compensation point. Water Air Soil Poll 80:373-382. https://doi.org/10.1007/BF01 189687

71. Caffrey PF, Ondov JM, Zufall MJ, Davidson Cl (1998) Determination of size-dependent dry particle deposition velocities with multiple intrinsic elemental tracers. Environ Sci Technol 32:1615-1622. https://doi. org/10.1021/es970644f

72. Converse AD, Riscassi AL, Scanlon TM (2010) Seasonal variability in gaseous mercury fluxes measured in a high-elevation meadow. Atmos Environ 44:2176-2185. https://doi.org/10.1016/j.atmosenv.2010.03.024

73. Carpi A, Fostier AH, Orta OR, dos Santos JC, Gittings M (2014) Gaseous mercury Carp emissions from soil following forest loss and land use changes: field experiments in the United States and Brazil. Atmos Environ 96:423-429. https://doi.org/10.1016/j.atmosenv.2014.08.004

74. Zhang H, Lindberg SE, Marsik FJ, Keeler GJ (2001) Mercury air/surface exchange kinetics of background soils of the Tahquamenon River watershed in the Michigan Upper Peninsula. Water Air Soil Poll 126:151-169

75. Ferrari CP, Dommerguea A, Veysseyrea A, Planchona F, Boutrona CF (2002) Mercury speciation in the French seasonal snow cover. Sci Total Environ 287:61-69. https://doi.org/10.1016/S0048-9697(01)00999-8

76. Gustin MS, Biester H, Kim CS (2002) Investigation of the light-enhanced emission of mercury from naturally enriched substrates. Atmos Environ 36:3241-3254. https://doi.org/10.1016/S1352-2310(02)00329-1

77. Poissant L, Pilote M, Xu X, Zhang H, Beauvais C (2004) Atmospheric mercury speciation and deposition in the Bay St. Francois wetlands. J Geophys Res 109:1-14. https://doi.org/10.1029/2003JD004364

78. Gustin MS (2003) Are mercury emissions from geologic sources significant? A status report. Sci Total Environ. 304:153-167. https://doi. org/10.1016/S0048-9697(02)00565-X

79. Gustin MS, Lindberg SE (2005) Terrestial Hg Fluxes: is the next exchange up, down, or neither? In: Pirrone N, Mahaffey KR (eds) Dynamics of mercury pollution on regional and global scales. Springer, Boston, pp 241-259. https://doi.org/10.1007/0-387-24494-8_11

80. Stamenkovic J, Gustin MS (2007) Evaluation of use of EcoCELL technology for quantifying total gaseous mercury fluxes over background substrates. Atmos Environ 41:3702-3712. https://doi.org/10.1016/j. atmosenv.2006.12.037

81. Ericksen JA, Gustin MS, Xin M, Weisberg PJ, Fernandez GCJ (2006) Air-soil exchange of mercury from background soils in the United States. Sci Total Environ 366:851-863. https://doi.org/10.1016/j.scito tenv.2005.08.019 
82. Mason RP, Pirrone N, Hedgecock I, Suzuki N, Levin L (2010) Conceptual overview. In: Pirrone N, Keating T (eds) Hemispheric transport of air pollution — part B. United Nations Publication, New York, pp 1-19. https ://doi.org/10.18356/38ccc958-en

83. Carpi A, Lindberg SE (1997) Sunlight-mediated emission of elemental mercury from soil amended with municipal sewage sludge. Environ Sci Technol 31:2085-2091. https://doi.org/10.1021/Es960910+

84. Zhu W, Lin CJ, Wang X, Sommar J, Fu X, Feng X (2016) Global observations and modeling of atmosphere-surface exchange of elemental mercury: a critical review. Atmos Chem Phys 16:4451-4480. https://doi. org/10.5194/acp-16-4451-2016

85. Osterwalder S, Huang JH, Shetaya WH, Agnan Y, Frossard A, Frey B et al (2019) Mercury emission from industrially contaminated soils in relation to chemical, microbial, and meteorological factors. Environ Pollut 250:944-952. https://doi.org/10.1016/j.envpol.2019.03.093

86. Gabriel MC, Williamson DG, Brooks S, Zhang H, Lindberg S (2005) Spatial variability of mercury emissions from soils in a southeastern US urban environment. Environ Geol 48:955-964. https://doi.org/10.1007/s0025 4-005-0043-x

87. Ma M, Wang D, Sun R, Shen Y, Huang L (2013) Gaseous mercury emissions from subtropical forested and open field soils in a national nature reserve, southwest. China Atmos Environ 64:116-123. https://doi. org/10.1016/j.atmosenv.2012.09.038

88. Wang X, Lin CJ, Yuan W, Sommar J, Zhu W, Feng X (2016) Emission-dominated gas exchange of elemental mercury vapor over natural surfaces in China. Atmos Chem Phys 16:11125-11143. https://doi.org/10.5194/ acp-16-11125-2016

89. Sommar J, Zhu W, Shang L, Lin CJ, Feng XB (2015) Seasonal variations in metallic mercury $(\mathrm{Hg}$ O) vapor exchange over biannual wheatcorn rotation cropland in the North China Plain. Biogeosci Discuss 12:16105-16158. https://doi.org/10.5194/bgd-12-16105-2015

90. Gao Y, Wang Z, Zhang X, Wang C (2020) Observation and estimation of mercury exchange fluxes from soil under different crop cultivars and planting densities in North China Plain. Environ Pollut 259:113833. https ://doi.org/10.1016/j.envpol.2019.113833

91. Bishop K, Shanley JB, Riscassi A, de Wit HA, Eklöf K, Meng B et al (2020) Recent advances in understanding and measurement of mercury in the environment: terrestrial Hg cycling. Sci Total Environ 721:137647. https ://doi.org/10.1016/j.scitotenv.2020.137647

92. Qiu G, Feng X, Wang S, Shang L (2006) Environmental contamination of mercury from $\mathrm{Hg}$-mining areas in Wuchuan, northeastern Guizhou, China. Environ Pollut 142:549-558. https://doi.org/10.1016/j.envpo I.2005.10.015

93. Li Q, Tang L, Qiu G, Liu C (2020) Total mercury and methylmercury in the soil and vegetation of a riparian zone along a mercury-impacted reservoir. Sci Total Environ 738:139794. https://doi.org/10.1016/j.scito tenv.2020.139794

94. Goulet RR, Holmes J, Tessier A, Wang F, Siciliano SD, Page B et al (2007) Mercury methylation in sediments of a riverine marsh: the role of redox conditions sulfur chemistry and microbial communities. Geochim Cosmochim Ac. 71:3396-3406

95. Windham-Myers L, Marvin-DiPasquale M, Kakouros E, Agee JL, Kieu LH, Stricker CA et al (2014) Mercury cycling in agricultural and managed wetlands of California, USA: seasonal influences of vegetation on mercury methylation, storage, and transport. Sci Total Environ 484:308-318. https://doi.org/10.1016/j.scitotenv.2013.05.027

96. Kronberg RM, Jiskra M, Wiederhold JG, Bjorn E, Skyllberg U (2016) Methyl mercury formation in hillslope soils of boreal forests: the role of forest harvest and anaerobic microbes. Environ Sci Technol 50:91779186. https://doi.org/10.1021/acs.est.6b00762

97. Gnamuš A, Byrne AR, Horvat M (2000) Mercury in the soil-plant-deerpredator food chain of a temperate forest in Slovenia. Environ Sci Technol 34:3337-3345. https://doi.org/10.1021/es991419w

98. Meng B, Feng X, Qiu G, Cai Y, Wang D, Li P et al (2010) Distribution patterns of inorganic mercury and methylmercury in tissues of rice (Oryza sativa L.) plants and possible bioaccumulation pathways. J Agr Food Chem 58:4951-4958. https://doi.org/10.1021/jf904557x

99. Gilli R, Karlen C, Weber M, Rüegg J, Barmettler K, Biester H et al (2018) Speciation and mobility of mercury in soils contaminated by legacy emissions from a chemical factory in the Rhône valley in canton of
Valais. Switzerland. Soil Systems 2:44. https://doi.org/10.3390/soilsystem s2030044

100. Lima FRD, Martins GC, Silva AO, Vasques ICF, Engelhardt MM, Cândido GS et al (2019) Critical mercury concentration in tropical soils: impact on plants and soil biological attributes. Sci Total Environ 666:472-479. https://doi.org/10.1016/j.scitotenv.2019.02.216

101. Gonzalez-Raymat H, Liu G, Liriano C, Li Y, Yin Y, Shi J et al (2017) Elemental mercury: its unique properties affect its behavior and fate in the environment. Environ Pollut 229:69-86. https://doi.org/10.1016/.envpo I.2017.04.101

102. Xu J, Buck M, Eklöf K, Ahmed OO, Schaefer JK, Bishop K et al (2019) Mercury methylating microbial communities of boreal forest soils. Sci Rep 9:518. https://doi.org/10.1038/s41598-018-37383-z

103. Ling Q, Guo Y, Liang Y, Yin Y, Cai Y (2020) Microbial uptake of HgS nanoparticles and its effect on mercury methylation. Environ Chem 2:292-300. https://doi.org/10.7524/j.issn.0254-6108.2019112601

104. Bigham GN, Murray KJ, Masue-Slowey Y, Henry EA (2017) Biogeochemical controls on methylmercury in soils and sediments: implications for site management. Integr Environ Assess Manag 13:249-263. https://doi. org/10.1002/ieam.1822

105. Shahid M, Khalid S, Bibi I, Bundschuh J, Niazi NK, Dumat C (2020) A critical review of mercury speciation, bioavailability, toxicity and detoxification in soil-plant environment: ecotoxicology and health risk assessment. Sci Total Environ 711:134749. https://doi.org/10.1016/j.scito tenv.2019.134749

106. Zhao L, Qiu G, Anderson CW, Meng B, Wang D, Shang L et al (2016) Mercury methylation in rice paddies and its possible controlling factors in the $\mathrm{Hg}$ mining area, Guizhou province, Southwest China. Environ Pollut 215:1-9. https://doi.org/10.1016/j.envpol.2016.05.001

107. Eklöf K, Bishop K, Bertilsson S, Björn E, Buck M, Skyllberg U et al (2018) Formation of mercury methylation hotspots as a consequence of forestry operations. Sci Total Environ 613:1069-1078. https://doi. org/10.1016/j.scitotenv.2017.09.151

108. Qiu G, Feng X, Wang S, Shang L (2005) Mercury and methylmercury in riparian soil, sediments, mine-waste calcines, and moss from abandoned Hg mines in east Guizhou province, southwestern China. Appl Geoch 20:627-638. https://doi.org/10.1016/j.apgeochem.2004.09.006

109. Xu X, Meng B, Zhang C, Feng X, Gu C, Guo J et al (2017) The local impact of a coal-fired power plant on inorganic mercury and methylmercury distribution in rice (Oryza sativa L.). Environ Pollut 223:1 1-18. https://doi.org/10.1016/j.envpol.2016.11.042

110. Mailman M, Bodaly RA (2005) Total mercury, methyl mercury, and carbon in fresh and burned plants and soil in Northwestern Ontario. Environ Pollut 138:161-166. https://doi.org/10.1016/j.envpol.2005.02.005

111. Schuster PF, Schaefer KM, Aiken GR, Antweiler RC, Dewild JF, Gryziec JD et al (2018) Permafrost stores a globally significant amount of mercury. Geophys Res Lett 45:1463-1471. https://doi.org/10.1002/2017GL0755 71

112. Hararuk O, Obrist D, Luo Y (2013) Modelling the sensitivity of soil mercury storage to climate-induced changes in soil carbon pools. Biogeosciences 10:2393-2407. https://doi.org/10.5194/bg-10-2393-2013

113. Amos HM, Sonke JE, Obrist D, Robins N, Hagan N, Horowitz HM, Mason RP et al (2015) Observational and modeling constraints on global anthropogenic enrichment of mercury. Environ Sci Technol 49:40364047. https://doi.org/10.1021/es5058665

114. Mason RP, Choi AL, Fitzgerald WF, Hammerschmidt CR, Lamborg CH, Soerensen AL et al (2012) Mercury biogeochemical cycling in the ocean and policy implications. Environ Res 119:101-117. https://doi. org/10.1016/j.envres.2012.03.013

115. Fitzgerald WF, Lamborg CH (2014) Geochemistry of mercury in the environment. In: Treatise on Geochemistry, 2nd edition

116. Amos HM, Jacob DJ, Streets DG, Sunderland EM (2013) Legacy impacts of all-time anthropogenic emissions on the global mercury cycle. Global Biogeoch Cy 27:410-421. https://doi.org/10.1002/gbc.20040

117. Wang J, Feng X, Anderson CW, Xing Y, Shang L (2012) Remediation of mercury contaminated sites-a review. J Hazard Mater 221:1-18. https:// doi.org/10.1016/j.jhazmat.2012.04.035

118. Li S, Jia Z (2018) Heavy metals in soils from a representative rapidly developing megacity (SW China): levels, source identification and apportionment. CATENA 163:414-423. https://doi.org/10.1016/j.caten a.2017.12.035 
119. Obrist D, Pearson C, Webster J, Kane T, Lin CJ, Aiken GR et al (2016) A synthesis of terrestrial mercury in the western United States: spatial distribution defined by land cover and plant productivity. Sci Total Environ 568:522-535. https://doi.org/10.1016/j.scitotenv.2015.11.104

120. Tóth G, Hermann T, Szatmári G, Pásztor L (2016) Maps of heavy metals in the soils of the European Union and proposed priority areas for detailed assessment. Sci Total Environ 565:1054-1062. https://doi.org/10.1016/j. scitotenv.2016.05.115

121. Lima LC, Egreja Filho FB, Linhares LA, Windmoller CC, Yoshida MI (2015) Accumulation and oxidation of elemental mercury in tropical soils. Chemosphere 134:181-191. https://doi.org/10.1016/j.chemospher e.2015.04.020

122. Sharma R, Ramteke S, Patel KS, Kumar S, Sarangi B, Agrawal SG et al (2015) Contamination of lead and mercury in coal basin of India. J Environ Prot 6:1430-1441. https://doi.org/10.4236/jep.2015.612124

123. Taylor M (2014) Soil quality monitoring in the Waikato Region 2012. WRC Technical Report 2013/49, Waikato Regional Council, Hamilton, New Zealand. http://www.waikatoregion.govt.nz/tr201349/. Accessed 3 Sept 2014

124. Halbach K, Mikkelsen $\varnothing$, Berg T, Steinnes E (2017) The presence of mercury and other trace metals in surface soils in the Norwegian Arctic. Chemosphere 188:567-574. https://doi.org/10.1016/j.chemospher e.2017.09.012

125. Bailey EA, Gray JE, Theodorakos PM (2002) Mercury in vegetation and soils at abandoned mercury mines in southwestern Alaska. USA. Geochem Explor Environ A 2:275-285. https://doi.org/10.1144/1467-78730 2-032

126. Higueras P, Oyarzun R, Biester H, Lillo J, Lorenzo S (2003) A first insight into mercury distribution and speciation in soils from the Almadén mining district, Spain. J Geochem Explor 80(1):95-104. https://doi. org/10.1016/S0375-6742(03)00185-7

127. Gosar M, Šajn R, Biester H (2006) Binding of mercury in soils and attic dust in the Idrija mercury mine area (Slovenia). Sci Total Environ 369:150-162. https://doi.org/10.1016/j.scitotenv.2006.05.006

128. Bernaus A, Gaona X, van Ree D, Valiente M (2006) Determination of mercury in polluted soils surrounding a chlor-alkali plant: direct speciation by $X$-ray absorption spectroscopy techniques and preliminary geochemical characterisation of the area. Anal Chim Acta 565:73-80. https://doi.org/10.1016/j.aca.2006.02.020

129. Richardson JB, Moore L (2020) A tale of three cities: mercury in urban deciduous foliage and soils across land-uses in Poughkeepsie NY, Hartford CT, and Springfield MA USA. Sci Total Environ 715:136869. https:// doi.org/10.1016/j.scitotenv.2020.136869

130. Cheng H, Li M, Zhao C, Li K, Peng M, Qin A, Cheng X (2014) Overview of trace metals in the urban soil of 31 metropolises in China. J Geochem Explor 139:31-52. https://doi.org/10.1016/j.gexplo.2013.08.012

131. Tijhuis L, Brattli B, Sæther OM (2002) A geochemical survey of topsoil in the city of Oslo, Norway. Environ Geochem HIth 24:67-94. https://doi. org/10.1023/A:1013979700212

132. Manta DS, Angelone M, Bellanca A, Neri R, Sprovieri M (2002) Heavy metals in urban soils: a case study from the city of Palermo (Sicily), Italy. Sci Total Environ 300:229-243. https://doi.org/10.1016/S0048 -9697(02)00273-5

133. Rodrigues S, Pereira ME, Duarte AC, Ajmone-Marsan F, Davidson CM, Grčman H et al (2006) Mercury in urban soils: a comparison of local spatial variability in six European cities. Sci Total Environ 368:926-936. https://doi.org/10.1016/j.scitotenv.2006.04.008

134. Cheng H, Zhao C, Liu F, Yang K, Liu Y, Li M et al (2013) Mercury drop trend in urban soils in Beijing, China, since 1987. J Geochem Explor 124:195-202. https://doi.org/10.1016/j.gexplo.2012.09.007

135. Ottesen RT, Birke M, Finne TE, Gosar M, Locutura J, Reimann C et al (2013) Mercury in European agricultural and grazing land soils. Appl Geoch 33:1-12. https://doi.org/10.1016/j.apgeochem.2012.12.013

136. Loska K, Wiechuła D, Korus I (2004) Metal contamination of farming soils affected by industry. Environ Int 30:159-165. https://doi.org/10.1016/ S0160-4120(03)00157-0

137. Ahmadi M, Akhbarizadeh R, Haghighifard NJ, Barzegar G, Jorfi S (2019) Geochemical determination and pollution assessment of heavy metals in agricultural soils of south western of Iran. J Environ Health Sci Eng. https://doi.org/10.1007/s40201-019-00379-6
138. Navrátil T, Shanley J, Rohovec J, Hojdová M, Pení̌ek V, Buchtová J (2014) Distribution and pools of mercury in Czech forest soils. Water Air Soil Poll 225:1829. https://doi.org/10.1007/s11270-013-1829-1

139. Åkerblom S, Meili M, Bringmark L, Johansson K, Kleja DB, Bergkvist B (2008) Partitioning of $\mathrm{Hg}$ between solid and dissolved organic matter in the humus layer of boreal forests. Water Air Soil Poll 189:239-252. https ://doi.org/10.1007/s11270-007-9571-1

140. Boszke L, Kowalski A, Siepak J (2004) Grain size partitioning of mercury in sediments of the middle Odra River (Germany/Poland). Water Air Soil Poll 159:125-138. https://doi.org/10.1023/B:WATE.0000049171.22781 .bd

141. Fiorentino JC, Enzweiler J, Angélica RS (2011) Geochemistry of mercury along a soil profile compared to other elements and to the parental rock: evidence of external input. Water Air Soil Poll 221:63-75. https:// doi.org/10.1007/s11270-011-0769-x

142. do Valle CM, Santana GP, Augusti R, Egreja Filho FB, Windmöller CC (2005) Speciation and quantification of mercury in Oxisol, Ultisol, and Spodosol from Amazon (Manaus, Brazil). Chemosphere 58:779-792. https://doi.org/10.1016/j.chemosphere.2004.09.005

143. Armesto AG, Bibián-Núñez L, Campillo-Cora C, Pontevedra-Pombal X, Arias-Estévez M, Nóvoa-Muñoz JC (2018) Total mercury distribution among soil aggregate size fractions in a temperate forest podzol. Span J Soil Sci 8:190-202. https://doi.org/10.3232/SJSS.2018.V8.N1.05

144. Yin R, Gu C, Feng X, Hurley JP, Krabbenhoft DP, Lepak RF et al (2016) Distribution and geochemical speciation of soil mercury in Wanshan Hg mine: effects of cultivation. Geoderma 272:32-38. https://doi. org/10.1016/j.jes.2018.04.028

145. Wang DY, Qing CL, Guo TY, Guo YJ (1997) Effects of humic acid on transport and transformation of mercury in soil-plant systems. Water Air Soil Poll 95:35-43. https://doi.org/10.1007/BF02406154

146. Smith T, Pitts K, McGarvey JA, Summers AO (1998) Bacterial oxidation of mercury metal vapor, $\mathrm{Hg}(0)$. Appl Environ Microbiol 64:1328-1332

147. Colombo MJ, Ha J, Reinfelder JR, Barkay T, Yee N (2013) Anaerobic oxidation of $\mathrm{Hg}(0)$ and methylmercury formation by Desulfovibrio desulfuricans ND132. Geochim Cosmochim Ac 112:166-177. https://doi. org/10.1016/j.gca.2013.03.001

148. Colombo MJ, Ha J, Reinfelder JR, Barkay T, Yee N (2014) Oxidation of $\mathrm{Hg}(0)$ to $\mathrm{Hg}(\mathrm{II})$ by diverse anaerobic bacteria. Chem Geol 363:334-340. https://doi.org/10.1016/j.chemgeo.2013.11.020

149. Gustin MS, Ericksen JA, Schorran DE, Johnson DW, Lindberg SE, Coleman JS (2004) Application of controlled mesocosms for understanding mercury air-soil—plant exchange. Environ Sci Technol 38:6044-6050. https://doi.org/10.1021/es0487933

150. Fantozzi L, Ferrara R, Dini F, Tamburello L, Pirrone N, Sprovieri F (2013) Study on the reduction of atmospheric mercury emissions from mine waste enriched soils through native grass cover in the Mt. Amiata region of Italy. Environ Res 125:69-74. https://doi.org/10.1016/j.envre s.2013.02.004

151. Mazur M, Mitchell CPJ, Eckley CS, Eggert SL, Kolka RK, Sebestyen SD et al (2014) Gaseous mercury fluxes from forest soils in response to forest harvesting intensity: a field manipulation experiment. Sci Total Environ 496:678-687. https://doi.org/10.1016/j.scitotenv.2014.06.058

152. Ericksen JA, Gustin MS, Schorran DE, Johnson DW, Lindberg SE, Coleman JS (2003) Accumulation of atmospheric mercury in forest foliage. Atmos Environ 37:1613-1622. https://doi.org/10.1016/S1352 $-2310(03) 00008-6$

153. Leonard TL, Taylor GE Jr, Gustin MS, Fernandez GC (1998) Mercury and plants in contaminated soils: 1. Uptake, partitioning, and emission to the atmosphere. Environ Toxicol Chem 17:2063-2071. https://doi. org/10.1002/etc.5620171024

154. Frescholtz TF, Gustin MS, Schorran DE, Fernandez GC (2003) Assessing the source of mercury in foliar tissue of quaking aspen. Environ Toxicol Chem 22:2114-2119. https://doi.org/10.1002/etc.5620220922

155. Assad M, Parelle J, Cazaux D, Gimbert F, Chalot M, Tatin-Froux F (2016) Mercury uptake into poplar leaves. Chemosphere 146:1-7. https://doi. org/10.1016/j.chemosphere.2015.11.103

156. Fleck JA, Grigal DF, Nater EA (1999) Mercury uptake by trees: an observational experiment. Water Air Soil Poll. 115:513-523. https://doi. org/10.1023/A:1005194608598

157. Dago A, González I, Ariño C, Martínez-Coronado A, Hiqueras P, DíazCruz JM et al (2014) Evaluation of mercury stress in plants from the 
Almadén mining district by analysis of phytochelatins and their $\mathrm{Hg}$ complexes. Environ Sci Technol 8:6256-6263. https://doi.org/10.1021/ es405619y

158. Laacouri A, Nater EA, Kolka RK (2013) Distribution and uptake dynamics of mercury in leaves of common deciduous tree species in Minnesota, USA. Environ Sci Technol 47:10462-10470. https://doi.org/10.1021/ es401357z

159. Arnold J, Gustin MS, Weisberg PJ (2018) Evidence for nonstomatal uptake of $\mathrm{Hg}$ by aspen and translocation of $\mathrm{Hg}$ from foliage to tree rings in Austrian pine. Environ Sci Technol 52:1174-1182. https://doi. org/10.1021/acs.est.7b04468

160. Moreno-Jiménez E, Gamarra R, Carpena-Ruiz RO, Millán R, Peñalosa $J M$, Esteban E (2006) Mercury bioaccumulation and phytotoxicity in two wild plant species of Almadén area. Chemosphere 63:19691973. https://doi.org/10.1016/j.chemosphere.2005.09.043

161. Qian X, Wu Y, Zhou H, Xu X, Xu Z, Shang L et al (2018) Total mercury and methylmercury accumulation in wild plants grown at wastelands composed of mine tailings: insights into potential candidates for phytoremediation. Environ Pollut 239:757-767. https://doi. org/10.1016/j.envpol.2018.04.105

162. De Temmerman L, Waegeneers N, Claeys N, Roekens E (2009) Comparison of concentrations of mercury in ambient air to its accumulation by leafy vegetables: an important step in terrestrial food chain analysis. Environ Poll 157:1337-1341. https://doi.org/10.1016/j.envpo 1.2008.11.035

163. Egler SG, Rodrigues-Filho S, Villas-Bôas RC, Beinhoff C (2006) Evaluation of mercury pollution in cultivated and wild plants from two small communities of the Tapajós gold mining reserve, Pará State. Brazil. Sci Total Environ 368(1):424-433

164. Svoboda L, Havličková B, Kalač P (2006) Contents of cadmium, mercury and lead in edible mushrooms growing in a historical silvermining area. Food Chem 96:580-585. https://doi.org/10.1016/j.foodc hem.2005.03.012

165. Falandysz J, Mędyk M, Treu R (2018) Bio-concentration potential and associations of heavy metals in Amanita muscaria (L.) Lam. from northern regions of Poland. Environ Sci Pollut R. 25(25):25190-25206. https://doi.org/10.1007/s11356-018-2603-0

166. Millhollen AG, Gustin MS, Obrist D (2006) Foliar mercury accumulation and exchange for three tree species. Environ Sci Technol 40:6001-6006. https://doi.org/10.1021/es0609194

167. Asati A, Pichhode M, Nikhil K (2016) Effect of heavy metals on plants: an overview. Int J Appl Innov Eng Mgmt 5:56-66

168. Ahammad SJ, Sumithra S, Senthilkumar P (2018) Mercury uptake and translocation by indigenous plants. Rasayan J Chem. 11:1-12. https:// doi.org/10.7324/RJC.2018.1111726

169. Safari F, Akramian M, Salehi-Arjmand H, Khadivi A (2019) Physiological and molecular mechanisms underlying salicylic acid-mitigated mercury toxicity in lemon balm (Melissa officinalis L.). Ecotoxicol Environ Saf 183:109542. https://doi.org/10.1016/j.ecoenv.2019.109542

170. Zhou ZS, Wang SJ, Yang ZM (2008) Biological detection and analysis of mercury toxicity to alfalfa (Medicago sativa) plants. Chemosphere 70:1500-1509. https://doi.org/10.1016/j.chemosphere.2007.08.028

171. Azevedo R, Rodriguez E (2012) Phytotoxicity of mercury in plants: a review. J Bot. https://doi.org/10.1155/2012/848614

172. Patra M, Sharma A (2000) Mercury toxicity in plants. Bot Rev 66:379422. https://doi.org/10.1007/BF02868923

173. Moreno FN, Anderson CW, Stewart RB, Robinson BH (2004) Phytoremediation of mercury-contaminated mine tailings by induced plant-mercury accumulation. Environ Pra 6:65-175. https://doi. org/10.1017/S1466046604000274

174. Obrist D (2007) Atmospheric mercury pollution due to losses of terrestrial carbon pools? Biogeochemistry 85:119-123. https://doi. org/10.1007/s10533-007-9108-0

175. Lomonte C, Doronila Al, Gregory D, Baker AJ, Kolev SD (2010) Phytotoxicity of biosolids and screening of selected plant species with potential for mercury phytoextraction. J Hazard Mater 173:494-501. https://doi.org/10.1016/j.jhazmat.2009.08.112

176. Fasani E, Manara A, Martini F, Furini A, DalCorso G (2018) The potential of genetic engineering of plants for the remediation of soils contaminated with heavy metals. Plant, Cell Environ 41:1201-1232. https://doi.org/10.1111/pce.12963
177. Ahmed I, Sebastain A, Prasad MNV, Kirti PB (2019) Emerging trends in transgenic technology for phytoremediation of toxic metals and metalloids. In: Prasad MNV (ed) Transgenic plant technology for remediation of toxic metals and metalloids. Academic Press, Cambridge, pp 43-62

178. Kim Y-O, Bae H-J, Cho E, Kang H (2017) Exogenous glutathione enhances mercury tolerance by inhibiting mercury entry into plant cells. Front Plant Sci 8:683. https://doi.org/10.3389/fpls.2017.00683

179. Cho UH, Park JO (2000) Mercury-induced oxidative stress in tomato seedlings. Plant Sci 156:1-9. https://doi.org/10.1016/S0168 $-9452(00) 00227-2$

180. Israr M, Sahi SV (2006) Antioxidative responses to mercury in the cell cultures of Sesbania drummondii. Plant Physiol Bioch 44:590-595. https ://doi.org/10.1016/j.plaphy.2006.09.021

181. Zhang T, Lu Q, Su C, Yang Y, Hu D, Xu Q (2017) Mercury induced oxidative stress, DNA damage, and activation of antioxidative system and Hsp70 induction in duckweed (Lemna minor). Ecotoxicol Environ Saf 143:46-56. https://doi.org/10.1016/j.ecoenv.2017.04.058

182. Gómez-Jacinto V, García-Barrera T, Gómez-Ariza JL, Garbayo-Nores I, Vílchez-Lobato C (2015) Elucidation of the defence mechanism in microalgae Chlorella sorokiniana under mercury exposure. Identification of Hg-phytochelatins. Chem Biol Interact 238:82-90. https://doi. org/10.1016/j.cbi.2015.06.013

183. Wani AB, Chadar H, Wani AH, Singh S, Upadhyay N (2017) Salicylic acid to decrease plant stress. Environ Chem Lett 15:101-123. https://doi. org/10.1007/s10311-016-0584-0

184. Kováčik J, Rotková G, Bujdoš M, Babula P, Peterková V, Matúš P (2017) Ascorbic acid protects Coccomyxa subellipsoidea against metal toxicity through modulation of ROS/NO balance and metal uptake. J Hazar Mat 339:200-207. https://doi.org/10.1016/j.jhazmat.2017.06.035

185. Zhou X, Gao A, Zhang C, Xu W, Shi X (2017) Exogenous selenium alleviates mercury toxicity by preventing oxidative stress in rice (Oryza sativa) seedlings. Int J Agric Biol 19:1593-1600

186. Seneviratne M, Rajakaruna N, Rizwan M, Madawala HMSP, Yong Sik Ok YS, Vithanage M (2019) Heavy metal-induced oxidative stress on seed germination and seedling development: a critical review. Environ Geochem Health 41:1813-1831. https://doi.org/10.1007/s1065 3-017-0005-8

187. Hasanuzzaman M, Hossain MA, da Silva JAT, Fujita M (2012) Plant response and tolerance to abiotic oxidative stress: antioxidant defense is a key factor. In: Venkateswarlu B, Shanker A, Shanker C, Maheswari M (eds) Crop stress and its management: perspectives and strategies. Springer, Dordrecht, pp 261-315. https://doi. org/10.1007/978-94-007-2220-0

188. Cargnelutti D, Tabaldi LA, Spanevello RM, de Oliveira Jucoski G, Battisti $\checkmark$, Redin M et al (2006) Mercury toxicity induces oxidative stress in growing cucumber seedlings. Chemosphere 65:999-1006. https://doi. org/10.1016/j.chemosphere.2006.03.037

189. Patra M, Bhowmik N, Bandopadhyay B, Sharma A (2004) Comparison of mercury, lead and arsenic with respect to genotoxic effects on plant systems and the development of genetic tolerance. Environ Exp Bot 52:199-223. https://doi.org/10.1016/j.envexpbot.2004.02.009

190. Nagajyoti PC, Lee KD, Sreekanth TVM (2010) Heavy metals, occurrence and toxicity for plants: a review. Environ Chem Lett 8:199-216. https:// doi.org/10.1007/s10311-010-0297-8

191. Marrugo-Negrete J, Durango-Hernández J, Pinedo-Hernández J, Enamorado-Montes G, Díez S (2016) Mercury uptake and effects on growth in Jatropha curcas. J Environ Sci 48:120-125. https://doi.org/10.1016/j. jes.2015.10.036

192. Teixeira DC, Lacerda LD, Silva-Filho EV (2018) Foliar mercury content from tropical trees and its correlation with physiological parameters in situ. Environ Pollut 242:1050-1057. https://doi.org/10.1016/j.envpo 1.2018.07.120

193. Manikandan R, Sahi SV, Venkatachalam P (2015) Impact assessment of mercury accumulation and biochemical and molecular response of Mentha arvensis: a potential hyperaccumulator plant. Sci World J. https ://doi.org/10.1155/2015/715217

194. Mahbub KR, Krishnan K, Naidu R, Andrews S, Megharaj M (2017) Mercury toxicity to terrestrial biota. Ecol Indic 74:451-462. https://doi. org/10.1016/j.atmosenv.2005.07.067 
195. Zhou ZS, Huang SQ, Guo K, Mehta SK, Zhang PC, Zhi MY et al (2007) Metabolic adaptations to mercury-induced oxidative stress in roots of Medicago sativa L. J Inorg Biochem 101:1-9. https://doi.org/10.1016/j. jinorgbio.2006.05.011

196. Bash JO, Miller DR, Meyer TH, Bresnahan PA (2004) Northeast United States and Southeast Canada natural mercury emissions estimated with a surface emission model. Atmos Environ 38:5683-5692. https:// doi.org/10.1016/j.atmosenv.2004.05.058

197. Rea AW, Lindberg SE, Scherbatskoy T, Keeler GJ (2002) Mercury accumulation in foliage over time in two northern mixed-hardwood forests. Water Air Soil Pollut 133:49-67. https://doi.org/10.1023/A:1012919731 598

198. Magarelli G, Fostier AH (2005) Influence of deforestation on the mercury air/soil exchange in the Negro River Basin, Amazon. Atmos Environ 39:7518-7528. https://doi.org/10.1016/j.atmosenv.2005.07.067

199. Selin MS, Lindberg SE (2005) Terrestrial Hg fluxes: is the next exchange up, down, or neither? In: Pirrone N, Mahaffey KR (eds) Dynamics of mercury pollution on regional and global scales. Springer, Boston, pp 241-259. https://doi.org/10.1007/0-387-24494-8_11

200. Gustin MS, Engle M, Ericksen J, Lyman S, Stamenkovic J, Xin M (2006) Mercury exchange between the atmosphere and low mercury containing substrates. Appl Geoch 21:1913-1923. https://doi.org/10.1016/j. apgeochem.2006.08.007

201. Selin NE, Jacob DJ, Yantosca RM, Strode S, Jaeglé L, Sunderland EM (2008) Global 3D land, ocean, atmosphere model for mercury: present day versus preindustrial cycles and anthropogenic enrichment factors for deposition. Global Biogeoch Cy 22:1-13. https://doi. org/10.1029/2007GB003040

202. Gray JE, Theodorakos PM, Fey DL, Krabbenhoft DP (2015) Mercury concentrations and distribution in soil, water, mine waste leachates, and air in and around mercury mines in the Big Bend region, Texas. Environ Geochem Hlth. 37:35-48. https://doi.org/10.1007/s10653-014-9628-1

203. Wu G, Kang H, Zhang X, Shao H, Chu L, Ruan C (2010) A critical review on the bio-removal of hazardous heavy metals from contaminated soils: issues, progress, eco-environmental concerns and opportunities. J Hazard Mater 174:1-8. https://doi.org/10.1016/j.jhazmat.2009.09.113

204. Teršič T, Gosar M, Šajn R (2009) Impact of mining activities on soils and sediments at the historical mining area in Podljubelj, NW Slovenia. J Geochem Explor 100:1-10. https://doi.org/10.1016/j.gexplo.2008.02.005

205. Banásová V (1999) Vegetation on contaminated sites near an Hg mine and smelter. In: Ebinghaus RR, Turner RR, de Lacedra LD, Vasiljev O, Salomons W (eds) Mercury contaminated sites. Springer, Berlin, pp 321-335. https://doi.org/10.1007/978-3-662-03754-6

206. Boente C, Albuquerque MTD, Gerassis S, Rodríguez-Valdés E, Gallego JR (2019) A coupled multivariate statistics, geostatistical and machinelearning approach to address soil pollution in a prototypical Hg-mining site in a natural reserve. Chemosphere 218:767-777. https://doi. org/10.1016/j.chemosphere.2018.11.172

207. Wahsha M, Maleci L, Bini C (2019) The impact of former mining activity on soils and plants in the vicinity of an old mercury mine (Vallalta, Belluno, NE Italy). Geochem-Explor Envir Anal 19:171-175. https://doi. org/10.1144/geochem2018-040

208. Gemici Ü, Tarcan G, Somay AM, Akar T (2009) Factors controlling the element distribution in farming soils and water around the abandoned Halıköy mercury mine (Beydağ, Turkey). Appl Geoch 24:1908-1917. https://doi.org/10.1016/j.apgeochem.2009.07.004

209. Xiao R, Wang S, Li R, Wang JJ, Zhang Z (2017) Soil heavy metal contamination and health risks associated with artisanal gold mining in Tongguan, Shaanxi, China. Ecotox Environ Safe 141:17-24. https://doi. org/10.1016/j.ecoenv.2017.03.002

210. Yin $D, H e T$, Yin $R$, Zeng $L$ (2018) Effects of soil properties on production and bioaccumulation of methylmercury in rice paddies at a mercury mining area, China. J Environ Sci 68:194-205. https://doi.org/10.1016/j. jes.2018.04.028

211. Chiarantini L, Rimondi V, Benvenuti M, Beutel MW, Costagliola P, Gonnelli C et al (2016) Black pine (Pinus nigra) barks as biomonitors of airborne mercury pollution. Sci Total Environ 569:105-113. https://doi. org/10.1016/j.scitotenv.2016.06.029

212. Hissler C, Probst JL (2006) Impact of mercury atmospheric deposition on soils and streams in a mountainous catchment (Vosges, France) polluted by chlor-alkali industrial activity: the important trapping role of the organic matter. Sci Total Environ 361:163-178. https://doi. org/10.1016/j.scitotenv.2005.05.023

213. Grangeon S, Guédron S, Asta J, Sarret G, Charlet L (2012) Lichen and soil as indicators of an atmospheric mercury contamination in the vicinity of a chlor-alkali plant (Grenoble, France). Ecol Indic 13:178-183. https:// doi.org/10.1016/j.ecolind.2011.05.024

214. Ullrich SM, Ilyushchenko MA, Kamberov IM, Tanton TW (2007) Mercury contamination in the vicinity of a derelict chlor-alkali plant. Part I: sediment and water contamination of Lake Balkyldak and the River Irtysh. Sci Total Environ 381:1-16. https://doi.org/10.1016/j.scito tenv.2007.02.033

215. Esbrí JM, López-Berdonces MA, Fernández-Calderón S, Higueras P, Díez $S$ (2015) Atmospheric mercury pollution around a chlor-alkali plant in Flix (NE Spain): an integrated analysis. Environ Sci Pollut R 22:48424850. https://doi.org/10.1007/s11356-014-3305-x

216. Biester H, Müller G, Schöler HF (2002) Binding and mobility of mercury in soils contaminated by emissions from chlor-alkali plants. Sci Total Environ 284:191-203. https://doi.org/10.1016/S0048-9697(01)00885-3

217. Reis AT, Rodrigues SM, Araújo C, Coelho JP, Pereira E, Duarte AC (2009) Mercury contamination in the vicinity of a chlor-alkali plant and potential risks to local population. Sci Total Environ 407:2689-2700. https:// doi.org/10.1016/j.scitotenv.2008.10.065

218. Zheng N, Liu J, Wang Q, Liang Z (2011) Mercury contamination due to zinc smelting and chlor-alkali production in NE China. Appl Geoch 26(2):188-193. https://doi.org/10.1016/j.apgeochem.2010.11.018

219. Song Z, Li P, Ding L, Li Z, Zhu W, He T, Feng X (2018) Environmental mercury pollution by an abandoned chlor-alkali plant in Southwest China. J Geochem Explor 194:81-87. https://doi.org/10.1016/j.gexpl 0.2018 .07 .017

220. Zhu W, Li Z, Li P, Yu B, Lin CJ, Sommar J et al (2018) Re-emission of legacy mercury from soil adjacent to closed point sources of $\mathrm{Hg}$ emission. Environ Pollut 242:718-727. https://doi.org/10.1016/j.envpo I.2018.07.002

221. Reis AT, Rodrigues SM, Davidson CM, Pereira E, Duarte AC (2010) Extractability and mobility of mercury from agricultural soils surrounding industrial and mining contaminated areas. Chemosphere 81:1369-1377. https://doi.org/10.1016/j.chemosphere.2010.09.030

222. Liang J, Feng C, Zeng G, Gao X, Zhong M, Li X et al (2017) Spatial distribution and source identification of heavy metals in surface soils in a typical coal mine city, Lianyuan, China. Environ Pollut 225:681-690. https://doi.org/10.1016/j.envpol.2017.03.057

223. Wu Q, Wang S, Wang L, Liu F, Lin CJ, Zhang L et al (2014) Spatial distribution and accumulation of $\mathrm{Hg}$ in soil surrounding a $\mathrm{Zn} / \mathrm{Pb}$ smelter. Sci Total Environ 496:668-677. https://doi.org/10.1016/j.scito tenv.2014.02.067

224. Wang D, Shi X, Wei S (2003) Accumulation and transformation of atmospheric mercury in soil. Sci Total Environ 304:209-214. https://doi. org/10.1016/S0048-9697(02)00569-7

225. Navrátil T, Burns DA, Nováková T, Kaňa J, Rohovec J, Roll M et al (2018) Stability of mercury concentration measurements in archived soil and peat samples. Chemosphere 208:707-711. https://doi.org/10.1016/j. chemosphere.2018.06.033

226. Khan MN, Wasim AA, Sarwar A, Rasheed MF (2011) Assessment of heavy metal toxicants in the roadside soil along the N-5, National Highway, Pakistan. Environ Monit Assess 182:587-595. https://doi.org/10.1007/ s10661-011-1899-8

227. Beckers F, Awad YM, Beiyuan J, Abrigata J, Mothes S, Tsang DC et al (2019) Impact of biochar on mobilization, methylation, and ethylation of mercury under dynamic redox conditions in a contaminated floodplain soil. Environ Inter 127:276-290. https://doi.org/10.1016/j.envin t.2019.03.040

228. Bonanno G, Giudice RL, Pavone P (2012) Trace element biomonitoring using mosses in urban areas affected by mud volcanoes around Mt. Etna. The case of the Salinelle, Italy. Monit Assess 184:5181-5188. https ://doi.org/10.1007/s10661-011-2332-z

\section{Publisher's Note}

Springer Nature remains neutral with regard to jurisdictional claims in published maps and institutional affiliations. 